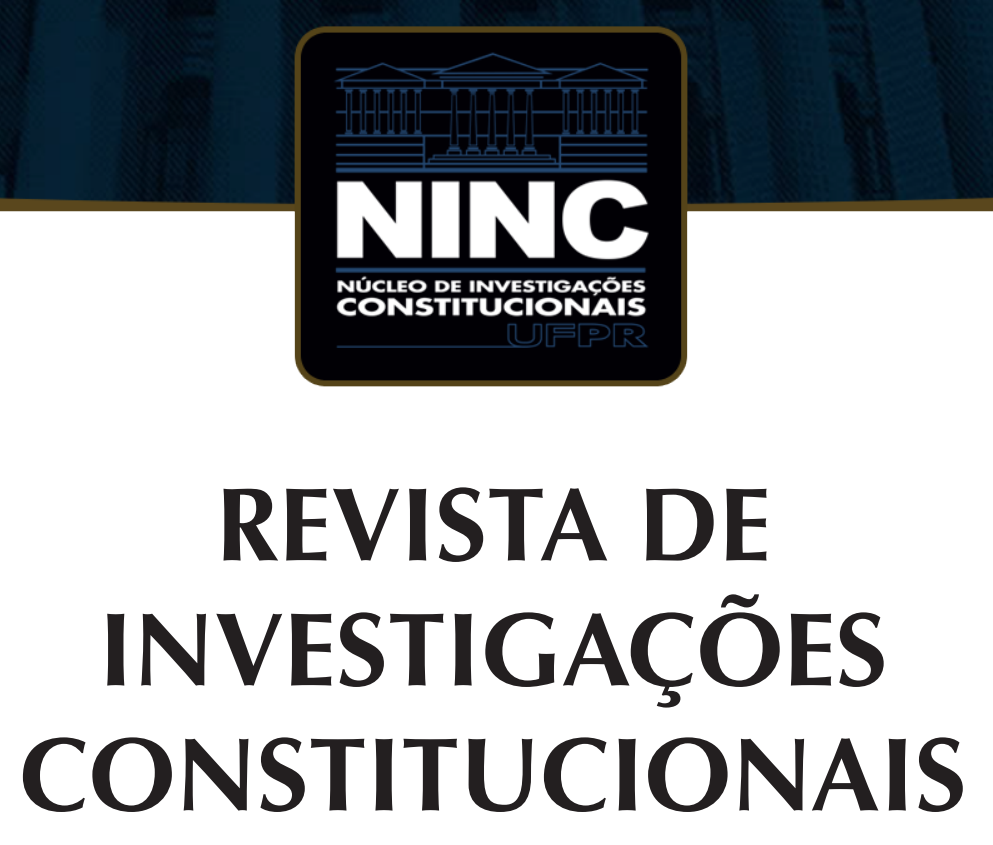

JOURNAL OF CONSTITUTIONAL RESEARCH

vol. 8 | n. 2 | maio/agosto 2021 | ISSN 2359-5639 | Periodicidade quadrimestral Curitiba | Núcleo de Investigações Constitucionais da UFPR | www.ninc.com.br 


\title{
Poder Judiciário e estado de exceção: direito de resistência ao ativismo judicial
}

\section{The judiciary and the state of exception: right to resist judicial activism}

\author{
RICARDO MARCONDES MARTINS ${ }^{\text {1, * }}$ \\ ' Pontifícia Universidade Católica de São Paulo (São Paulo, São Paulo, Brasil) \\ ricmarconde@uol.com.br \\ https://orcid.org/0000-0002-4161-9390 \\ Recebido/Received: 21.02.2020 / February $21^{\text {st }}, 2020$ \\ Aprovado/Approved: $17.05 .2021 /$ May $17^{\text {th }}, 2020$
}

\begin{abstract}
Resumo
Perquire-se, sob a perspectiva jurídico-dogmática, a relação entre o Poder Judiciário brasileiro e o estado de exceção. $O$ estado de exceção lícito consiste nos estados de defesa e de sítio, situações constitucionalmente regradas, próprias do Estado de direito. $\mathrm{O}$ estado de exceção ilícito, ao revés, decorre da falência das instituições estatais no cumprimento de sua missão constitucional, e é atentatório ao Estado de Direito. O erro do Judiciário não é suficiente para configuração do estado de exceção ilícito, tendo em vista a regra de calibração inerente à coisa julgada. $\mathrm{O}$ erro jurisdicional só configura o estado de exceção quando resultar de uma falência institucional do Poder Judiciário. A revelação correta de normas implícitas ou o correto controle da discricionariedade não configuram ativismo judicial. Este só ocorre quando há desrespeito ao correto exercício da discricionariedade. A resistência ao ato jurisdicional equivocado não é, regra geral, admitida no Estado de Direito. Quando, porém, o ato jurisdicional configura grave injustiça, admite-se a resistência sem rompimento do direito vigente.
\end{abstract}

\section{Abstract}

This paper is intended to investigate and examine the relationship between the Brazilian Judiciary and the state of exception from the legal-dogmatic perspective. The lawful state of exception consists of states of defense and siege, constitutionally ruled situations, within the Rule of Law. The unlawful state of exception, on the other hand, stems from the complete failure of state institutions to comply with its constitutional mission, and violates the Rule of Law. An error committed by the Judiciary is not enough to configure the unlawful state of exception, in view of the calibration rule inherent to the principle underlying res judicata. A jurisdictional error only configures a state of exception when it results from an institutional collapse of the Judiciary. The correct disclosure of implicit norms or the correct control of discretion does not constitute judicial activism, which only occurs upon disrespect to the proper exercise of discretion. Resistance to an erroneous jurisdictional act is not allowed under the Rule of Law, as a general rule. However, when a jurisdictional act constitutes a serious injustice, resistance is allowed without amounting to a breach of the existing law.

Como citar esse artigo/How to cite this article: MARTINS, Ricardo Marcondes. Poder Judiciário e estado de exceção: direito de resistência ao ativismo judicial. Revista de Investigações Constitucionais, Curitiba, vol. 8, n. 2, p. 457-487, maio/ago. 2021. DOI: $10.5380 /$ rinc.v8i2.71729.

"Professor de Direito Administrativo da Faculdade de Direito da Pontifícia Universidade Católica de São Paulo (São Paulo-SP, Brasil). Doutor em Direito Administrativo pela PUC/SP. E-mail: ricmarconde@uol.com.br. 
Palavras-chave: estado de exceção; Poder Judiciário; estado de defesa; estado de sítio; função jurisdicional.
Keywords: state of exception; Judiciary; state of defense; estate of siege; jurisdictional function.

\section{SUMÁRIO}

1. Introito. 2. Estado de exceção lícito. 3. Poder Judiciário no Estado de Direito. 4. Estado de exceção ilícito. 5. Ativismo judicial. 6. Resistência no Estado de Direito; 7. Conclusão; 6. Referências.

\section{INTROITO}

Pedro Estevam Alves Pinto Serrano, constitucionalista da PUC-SP, em estudo publicado em 2016, apresenta uma tese que, pela sua importância, provoca acuradas reflexões. Considera que nos países de capitalismo tardio e periférico, como os países da América Latina, incluído o Brasil, vivencia-se um "estado de exceção permanente" que convive com um "estado de direito permanente"1. Esse "estado de exceção" é estabelecido com base na "figura do inimigo"2: na Alemanha Nazista elegeu-se como inimigo o judeu, um inimigo étnico; nos Estados Unidos da América, após os atos terroristas de 11 de setembro de 2001, elegeu-se como inimigo o muçulmano, de feição religiosa; na ditadura militar brasileira elegeu-se como inimigo o comunista; contemporaneamente, no Brasil elegeu-se a figura mítica do "bandido", "pobre que vive à margem da população economicamente incluída" ${ }^{\prime \prime}$. Se, atualmente, nos países desenvolvidos a exceção geralmente é produzida pelo Legislador, tendo como foco cidadãos estrangeiros, nos países subdesenvolvidos, afirma Pedro Serrano, a principal fonte da exceção é a jurisdição e tem como foco nacionais ${ }^{4}$. Em suma, o Judiciário brasileiro seria fonte de um estado de exceção permanente para um expressivo contingente de brasileiros pobres.

Em homenagem ao Professor Pedro Serrano, jurista de escol, propõe-se submeter sua tese a uma análise crítica. Fixa-se, de início, um ponto de partida: pretende-se realizar uma reflexão sobre o Poder Judiciário e o estado de exceção sob uma perspectiva jurídico-dogmática ${ }^{5}$, com base em uma compreensão normativista do direito

1 SERRANO, Pedro Estevam Alves Pinto. Autoritarismo e golpes na América Latina. São Paulo: Alameda, 2016, p. 27. Ver, ainda: SERRANO, Pedro Estevam Alves; MAGANE, Renata Possi. A governabilidade de exceção permanente e a política neoliberal de gestão dos indesejáveis no Brasil. Revista de Investigações Constitucionais, Curitiba, vol. 7, n. 2, p. 517-547, maio/ago. 2020.

2 SERRANO, Pedro Estevam Alves Pinto. Autoritarismo e golpes na América Latina. São Paulo: Alameda, 2016, p. 69 et seq.

3 SERRANO, Pedro Estevam Alves Pinto. Autoritarismo e golpes na América Latina. São Paulo: Alameda, 2016, p. 99-100.

4 SERRANO, Pedro Estevam Alves Pinto. Autoritarismo e golpes na América Latina. São Paulo: Alameda, 2016, p. 105 e 143 et seq.

5 A perspectiva dogmática considera certos pontos de partida insuscetíveis de discussão, como a supremacia da Constituição e, em decorrência dela, a invalidade das normas que a contrariam; a perspectiva zetética não admite pontos que sejam indiscutíveis. Sobre ambas: FERRAZ JR., Tercio Sampaio. Introdução ao estudo do direito. 5. ed. São Paulo: Atlas, 2007, p. 39-51. 
brasileiro. Esse ponto de partida exige algumas explicações. O significado do Direito é uma questão aberta a múltiplas compreensões ${ }^{6}$. Assim, neste estudo adota-se uma perspectiva normativista, inspirada em Hans Kelsen ${ }^{7}$, e considera-se o Direito uma ordem normativa, um conjunto de normas vigentes em determinado território e em determinado momento histórico. A análise jurídica diz respeito à identificação das normas vigentes, à compreensão de seu sentido e alcance, à verificação de sua validade e de sua aptidão para serem aplicadas. Qualquer abordagem estranha à existência, validade e eficácia normativas é uma abordagem, nessa perspectiva, não jurídica ${ }^{8}$. A título de exemplo, considerações sobre o número de homicídios cometidos diariamente no Brasil ou sobre a relação entre a desigualdade social e esse número, apesar de importantes, não são questões jurídicas. Ainda que muitas pessoas morram de "morte matada" ainda que a aberrante injustiça social contribua para o aumento da criminalidade, esses fatos não alteram a validade da proibição da conduta de matar, estabelecida no artigo 121 do Código Penal.

Sob essa perspectiva, interessa o que deve ser (plano deôntico) e não o que é (plano ôntico). Retomando o exemplo: é proibido (plano jurídico do dever-ser), no ordenamento jurídico brasileiro, o homicídio, independente do fato de que muitos homicídios ocorrem diariamente (plano real do ser). Juridicamente, a pobreza e, pois, a desigualdade social, não são, em si, suficientes para afastar a responsabilização penal. Contudo, esta pode ser excluída pela miserabilidade, pois as condições sociais de marginalização, em que o sujeito perde a capacidade de se orientar pela norma, podem excluir a antijuridicidade ${ }^{10}$. O exame dos pressupostos dogmáticos da responsabilização penal consiste em um estudo jurídico-positivo.

A tese de Pedro Serrano, sob uma perspectiva empirista, não jurídico-positiva, é praticamente indiscutível. Não há como negar que um contingente significativo de pessoas, em geral as parcelas mais pobres da população, são alvo de reiterados erros na aplicação do direito pelo Judiciário. Mais do que erros pontuais: em uma perspectiva sociológica reconhece-se que o pobre é tomado como "inimigo", negando-se a ele os direitos fundamentais. Basta invocar como exemplo o sistema penitenciário brasileiro, já reconhecido formalmente pelo Supremo Tribunal Federal como violador da dignidade da pessoa humana, configurador de um verdadeiro "estado de coisas

6 Diferentemente do que ocorre em outras searas do conhecimento humano, cf. HART, Herbert Lionel Adolphus. $\mathbf{O}$ conceito de direito. Tradução: A. Ribeiro Mendes. 3. ed. Lisboa: Calouste Gulbenkian, 2001, p. 5.

7 KELSEN, Hans. Teoria pura do Direito. Tradução: João Baptista Machado. 6. ed. Coimbra: Armênio Amado Editora, 1984, p. 57.

8 Cf. BANDEIRA DE MELLO, Celso Antônio. Serviço público e concessão de serviço público. São Paulo: Malheiros, 2017, p. 67.

9 MELO NETO, João Cabral de. Morte e vida severina. In: MELO NETO, João Cabral de. Serial e antes. Rio de Janeiro: Nova Fronteira, 1997, p. 147.

10 Cf. TAVARES, Juarez. Fundamentos de teoria do delito. Florianópolis: Tirant lo Blanch, 2018, p. 366-370. 
inconstitucional"11, tema retomado adiante. É inegável a tese de que, sociologicamente, o Poder Judiciário vem sendo, em grande medida, responsável por essa situação, e, nesse sentido, é fonte de um estado de exceção. A questão que Pedro Serrano traz à baila oferece uma rica problemática para vários campos de estudo: política, sociologia, psicologia social. O que se propõe aqui é examiná-la com base em uma perspectiva jurídico-positiva ou dogmático-normativa.

\section{ESTADO DE EXCEÇÃO LÍCITO}

Do ponto de vista jurídico-positivo, deve-se diferenciar o estado de exceção lícito do estado de exceção ilícito. Como bem observa José Afonso da Silva, a expressão é grafada em letra minúscula para se referir a uma situação, a uma conjuntura, e não a um modelo jurídico de Estado ${ }^{12}$. A Constituição brasileira vigente disciplina no Capítulo I do Título V o chamado "sistema constitucional das crises"13, conjunto de normas constitucionais relativas à "defesa da Constituição contra processos violentos de mudança ou perturbação da ordem constitucional"14. Preveem-se duas situações de exceção: o estado de defesa e o estado de sítio, disciplinados nos artigos 136 a 141. Dois princípios fundamentais regem essas situações jurídicas: o princípio da necessidade, sem observância do qual há "puro golpe de estado", e o princípio da temporariedade, sem observância do qual há pura "ditadura"15. Segundo Aricê Moacyr Amaral Santos, nessas situações a "legalidade normal" é substituída por uma "legalidade extraordinária"16, mas isso se dá dentro do Estado de Direito e sob a égide da Constituição. São estados de exceção lícitos, não contrários ao Direito.

Tanto o estado de defesa como o estado de sítio são estabelecidos pela edição de um decreto do Presidente da República, ouvidos os Conselhos da República e de Defesa Nacional (condicionamentos formais). Ambos são admitidos para situações específicas (condicionamento objetivo). O estado de defesa é admitido em duas situações: a) grave e iminente instabilidade institucional; b) calamidades de grandes proporções na natureza. O estado de sítio é admitido em quatro situações: a) comoção grave de repercussão nacional; b) ocorrência de fatos que comprovem a ineficácia das medidas adotadas no estado de defesa; c) declaração de estado de guerra; d) resposta à agressão armada estrangeira. Ambos só são admitidos por um período determinado (condicionamento

\footnotetext{
11 STF, ADPF 347 MC, Rel. Min. Marco Aurélio, Tribunal Pleno, j. 09.09.2015, Processo Eletrônico DJe-031, Divulg. 18.02.2016, Public. 19.02.2016.

12 SILVA, José Afonso. Curso de direito constitucional positivo. 11. ed. São Paulo: Malheiros, 1996, p. 695.

13 SILVA, José Afonso. Curso de direito constitucional positivo. 11. ed. São Paulo: Malheiros, 1996, p. 693.

14 SILVA, José Afonso. Curso de direito constitucional positivo. 11. ed. São Paulo: Malheiros, 1996, p. 693.

15 SILVA, José Afonso. Curso de direito constitucional positivo. 11. ed. São Paulo: Malheiros, 1996, p. 694; SANTOS, Aricê Moacyr Amaral. O estado de emergência. São Paulo: Saraiva, 1981, p. 33.

16 SANTOS, Aricê Moacyr Amaral. O estado de emergência. São Paulo: Saraiva, 1981, p. 33.
} 
temporal): o estado de defesa deve durar no máximo trinta dias, admitida a prorrogação apenas uma vez, por igual período; o estado de sítio pode durar todo o tempo em que perdurar a guerra ou a agressão estrangeira ou, nas demais hipóteses, até trinta dias, admitindo-se, em relação a elas, quantas prorrogações forem necessárias, desde que cada prorrogação não seja superior a trinta dias. O estado de defesa é admitido para uma finalidade específica (condicionamento teleológico): a necessidade de "preservar ou prontamente reestabelecer a ordem pública ou a paz social". Em relação ao estado de sítio, a finalidade está implícita: ou a necessidade de defesa da soberania nacional em decorrência de agressões estrangeiras ou o agravamento das razões justificadoras do estado de defesa. Em ambos os casos, deve haver grave e concreto risco ao Estado ou às instituições democráticas. O estado de defesa deve se restringir a "locais restritos e determinados"; o estado de sítio pode abranger todo o território nacional, mas deve indicar expressamente as áreas em que serão executadas as medidas estatais nele admitidas (condicionamento espacial).

Além de todos esses condicionamentos, esses estados não estabelecem o arbítrio, atribuindo um "cheque em branco"17 às autoridades estatais. O efeito jurídico de seu estabelecimento é a possibilidade de determinadas restrições a certos direitos fundamentais que não são admitidas em situações de normalidade. Em relação ao estado de defesa, admitem-se: a) restrições aos direitos de reunião, sigilo de correspondência e de comunicação telegráfica e telefônica; b) ocupação e uso temporário de bens e serviços, apenas na hipótese de calamidade pública, devendo a União responder pelos danos e custos decorrentes; c) prisão por crimes contra o Estado determinada por ordem do executor da medida, não superior a dez dias, devendo ser comunicada imediatamente ao juiz competente, que deve relaxá-la se for ilegal, comunicação essa acompanhada de declaração da autoridade do estado físico e mental do detido no momento de sua atuação, sendo direito do preso requerer exame de corpo de delito à autoridade policial. Em relação ao estado de sítio, admitem-se: a) obrigação de permanência em localidade determinada; b) detenção em edifício não destinado a acusados ou condenados por crimes comuns; c) restrições à inviabilidade de correspondência, sigilo de comunicações, prestação de informações e à liberdade de imprensa, radiodifusão e televisão, na forma da lei; d) suspensão do direito de reunião; e) busca e apreensão de domicílio; f) intervenção nas empresas de serviço público; g) requisição de bens.

Nas situações de legalidade normal, fora dos estados de defesa e de sítio, os direitos fundamentais podem ser restringidos, seja pelo Legislador, seja pela Administração Pública, desde que respeitados o núcleo essencial do direito fundamental e a proporcionalidade. Não existem direitos fundamentais absolutos: todos são passíveis

17 A expressão foi utilizada por Caio Tácito, ao tratar da competência discricionária administrativa (TÁCITO, Caio. O abuso de poder administrativo no Brasil. In: TÁCITO, Caio. Temas de direito público: estudos e pareceres - v. 1. Rio de Janeiro: Renovar, 1997, p. 52). 
de restrição ${ }^{18}$. Há restrições estabelecidas diretamente pelo texto constitucional, como a vedação do anonimato à manifestação do pensamento (art. 50, IV). Nesses casos, a restrição fundamentada em regra constitucional expressa assenta-se no princípio formal que dá primazia às ponderações do constituinte (PfCo $)^{19}$.

Há restrições que são estabelecidas pelo Legislador com fundamento em uma cláusula de reserva expressa. Assim, por exemplo, o sigilo de comunicação telefônica pode ser restringido, por ordem judicial, "nas hipóteses e forma que a lei estabelecer" para fins de investigação criminal ou instrução processual penal (art. 5०., XII). A Lei Federal n 9.296/96, ao disciplinar as interceptações telefônicas, ampara-se nessa cláusula de reserva expressa. Nesses casos, as restrições se assentam no princípio formal que dá primazia às ponderações do legislador (Pfl), mas esse princípio é reforçado pelo princípio formal que dá primazia às ponderações do constituinte (Pfco).

Admitem-se, também, restrições estabelecidas pelo Legislador, mesmo sem cláusula de reserva expressa. $\mathrm{O}$ inciso XII do artigo $5^{\circ}$, por exemplo, não prevê a possibilidade de o Legislador restringir o sigilo de correspondência, mas é inequivocamente constitucional o parágrafo único do artigo 41 da Lei de Execução Penal (Lei n 7.210/84), que prevê a possibilidade de o diretor do presídio restringir o direito de correspondência do preso. A restrição assenta-se em uma cláusula de reserva implícita e, pois, no princípio formal que dá primazia às ponderações do legislador.

Ademais, as restrições podem decorrer diretamente da ponderação de princípios realizada no plano concreto, estando, nesse caso, alicerçadas no princípio formal que dá primazia às ponderações da administração pública ${ }^{20}$, se estabelecidas pela Ad-

\footnotetext{
18 Mesmo os direitos fundamentais estabelecidos sem cláusula de reserva expressa podem ser restringidos pelo Legislador, pela Administração Pública ou pelos particulares. A admissão dessa possibilidade tornou absolutamente superada a diferenciação proposta por José Afonso da Silva entre normas de eficácia plena e normas de eficácia contida, em que só as últimas poderiam ter sua eficácia restringida pelo Legislador (SILVA, José Afonso. Aplicabilidade das normas constitucionais. 4. ed. São Paulo: Malheiros, 2000, p. 81 et seq.). Sobre a possibilidade de restrição com base em uma cláusula de reserva implícita: ALEXY, Robert. Teoria dos direitos fundamentais. Tradução: Virgílio Afonso da Silva. São Paulo: Malheiros, 2008, p. 291 et seq.

Sobre a superação da teoria de José Afonso da Silva com base nessa admissibilidade: SILVA, Virgílio Afonso da. Direitos fundamentais. São Paulo: Malheiros, 2009, p. 218 et seq.

José Afonso da Silva, em sua obra mais recente, manifestou-se sobre as críticas e manteve sua posição (SILVA, José Afonso. Teoria do conhecimento constitucional. São Paulo: Malheiros, 2014, p. 565 et seq.). Para tanto, considerou artificial a teoria do suporte fático amplo, segundo a qual tudo que se subsume ao texto em que se extrai a norma do direito fundamental faz parte do suporte fático do referido direito; e, ao mesmo tempo, também rejeitou a teoria do suporte fático estrito, por também considerá-la artificial. Ao rejeitar ambas as teorias sob o singelo argumento de que as premissas que as apoiam são artificiais, expressou uma tautologia. No fundo, adota, sem reconhecer, a teoria do suporte fático estrito, que exclui do suporte fático dos direitos fundamentais certas condutas abrangidas pela enunciação textual. O grande problema dessa posição é que essas exclusões não são submetidas a um controle rigoroso.

19 Para uma explicação das restrições aos direitos fundamentais com base na teoria dos princípios formais, vide: MARTINS, Ricardo Marcondes. Teoria jurídica da liberdade. São Paulo: Contracorrente, 2015, p. 71-72.

20 Sobre o tema, vide: MARTINS, Ricardo Marcondes. Direito fundamental de acesso à informação. A\&C - Revista de Direito Administrativo \& Constitucional, Belo Horizonte, ano 14, n. 56, p. 127-146, abr./jun. 2014.
} 
ministração, ou no princípio formal que dá primazia às ponderações privadas, se estabelecidas pelos particulares ${ }^{21}$.

Sem embargo, as restrições aos direitos fundamentais devem respeitar os condicionamentos estabelecidos no texto constitucional e os respectivos pesos abstratos deles decorrentes. Quanto mais a decisão infraconstitucional se afastar das decisões extraídas da literalidade do texto, maior é o ônus argumentativo exigido para justificá-las. Por isso, é praticamente impossível, por exemplo, que seja considerada lícita uma interceptação telefônica não estabelecida por "ordem judicial", para fins diversos da "investigação criminal ou instrução processual penal" e pela forma e para hipóteses não previamente estabelecidas em lei (CF/88, art. 50, XII). Outro exemplo: é praticamente impossível que a prisão de alguém - fora da flagrância do delito ou de transgressão militar ou crime propriamente militar — , seja lícita se não for determinada por ordem escrita e fundamentada da autoridade judiciária competente (CF/88, art. 50, LXI). A teoria da ponderação, ainda que pressuponha a relatividade dos valores e, em decorrência dela, a resolução definitiva de problemas jurídicos tendo em vista a consideração das especificidades do caso concreto, não autoriza desprezar as regras constitucionais expressas $^{22}$.

Essa ressalva é fundamental para entender, juridicamente, os estados de defesa e de sítio: são situações próprias do Estado de direito em que se admitem restrições a certos direitos fundamentais não admitidas fora delas. Assim, por exemplo, em ambos é possível que a prisão seja determinada por autoridade diversa da autoridade jurisdicional fora das hipóteses discriminadas no inciso LXI do artigo 5. Outro exemplo: no estado de defesa é possível a censura, o que não se admite em situação de normalidade democrática (CF/88, arts. 50, IX, e 139, III) ${ }^{23}$. Considera-se inapropriada a expressão

21 Cf. MARTINS, Ricardo Marcondes. Abuso de direito e constitucionalização do direito privado. São Paulo: Malheiros, 2010, p. 74 et seq.

22 O texto constitucional, nas palavras de Konrad Hesse, é o "limite último da interpretação" (HESSE, Konrad. A interpretação constitucional. Tradução: Inocêncio Mártires Coelho. In: HESSE, Konrad. Temas fundamentais do direito constitucional. São Paulo: Saraiva, 2009, p. 106). Apesar de a interpretação não estar aprisionada à literalidade, não é dado ao intérprete reescrever o texto normativo. Sobre o tema: MARTINS, Ricardo Marcondes. Paradoxo da interpretação literal. Revista Colunistas de Direito do Estado, n. 102, 07 mar. 2016. Disponível em: http://goo.gl/bneUDH. Acesso em: 06 mar. 19.

23 Em 13.03.1974, o deputado federal Chico Pinto subiu à tribuna da Câmara dos Deputados para realizar um discurso em protesto contra a visita do ditador Pinochet e a homenagem feita a ele pelo governo brasileiro. Ernesto Geisel, ditador militar, mandou processar o deputado. Tratou-se da ação penal n. 219, que tramitara no STF. Em 26.09.1974, o Tribunal Regional Eleitoral da Bahia aceitou o pedido de impugnação da candidatura de Chico Pinto para mais um mandato de deputado, sob o argumento de que ele estava sendo processado no STF por crime contra a segurança nacional, decisão confirmada pelo TSE em 15.10.1974. Em 10.10.1974, o STF considerou não tipificado crime contra a segurança nacional, mas, sim, crime de difamação, condenou-o a seis meses de detenção e multa de nove cruzeiros, e suspendeu seus direitos políticos enquanto perdurassem os efeitos da condenação. Como ele repetira as afirmações de seu discurso em uma entrevista dada à Rádio Cultura de Feira de Santana, foi novamente processado e a ação fora levada a julgamento em 1977, quando o crime de difamação já havia prescrito. Cf. RECONDO, Felipe. Tanques e togas: o STF e a ditadura militar. São Paulo: Companhia das Letras, 2018, p. 235-253. Esse fato está certamente por trás da expressa ressalva estabelecida 
"legalidade extraordinária", utilizada para caracterizar esses estados de exceção: neles vigora a "legalidade normal", pois as medidas extraordinárias são disciplinadas na Constituição e nas leis. Observa-se que o $§ 1^{\circ}$ do artigo 136 exige que os termos e os limites das medidas estabelecidas no estado de defesa sejam disciplinados em lei; o inciso III do artigo 139 exige que as restrições nele previstas ocorram na forma da lei. Até o presente, essas leis não foram editadas pelo Congresso Nacional.

As restrições estatais, admitidas nessas situações excepcionais, são submetidas a rigoroso controle político e jurisdicional ${ }^{24}$. Decretado o estado de defesa ou sua prorrogação, o Presidente da República deve, dentro de vinte e quatro horas, submeter o ato ao Congresso Nacional, que decidirá por maioria absoluta dentro de dez dias contados do recebimento $(C F / 88$, art. 136, §4). Em relação ao estado de sítio, o controle político é mais intenso: só pode ser decretado ou prorrogado após prévia autorização do Congresso Nacional, que decidirá por maioria absoluta (CF/88, art. 137).

Além do controle político prévio, realizado sobre a decretação do estado de exceção, há também um controle político concomitante: a Mesa do Congresso Nacional deve designar uma Comissão composta por cinco de seus membros ${ }^{25}$ para acompanhar e fiscalizar a execução das medidas adotadas no estado de defesa e no estado de sítio.

Outrossim, tanto o ato de decretação e prorrogação, quanto todas as medidas estatais adotadas durante a respectiva vigência podem ser impugnadas no Poder Judiciário. Cessado o estado de exceção, deverão ser apuradas eventuais responsabilidades pelos ilícitos cometidos por seus executores ou agentes. Para facilitar essa apuração, exige o parágrafo único do artigo 141 da CF/88 que o Presidente da República relate em mensagem ao Congresso as medidas executadas, com especificação e justificação das providências adotadas, relação nominal dos atingidos e indicação das restrições aplicadas.

Este estudo não tem por objeto o estado de exceção lícito, que, nos termos aqui relatados, não configura exceção ao Estado de Direito, mas uma confirmação deste. Tanto o estado de defesa como o estado de sítio são situações jurídico-constitucionais, expressamente previstas no texto constitucional vigente. Pretende-se aqui estudar o estado de exceção ilícito, caracterizado pela falência das instituições estatais, mais propriamente do Poder Judiciário, na realização de sua missão constitucional. Trata-se de uma situação antitética ao Estado de Direito e à ordem constitucional. Para compreendê-la é mister realizar um breve exame da função jurisdicional.

\footnotetext{
no parágrafo único do art. 139 da CF/88: não se incluem nas restrições do estado de defesa "a difusão de pronunciamentos parlamentares efetuados em suas Casas Legislativas, desde que liberada pela respectiva Mesa".

24 Por todos: SILVA, José Afonso. Curso de direito constitucional positivo. 11. ed. São Paulo: Malheiros, 1996, p. 697-698 e 701-702.

25 Os membros da Comissão devem ser membros da Mesa do Congresso, que é composta pelos membros da Mesa do Senado Federal e pelos membros da Mesa da Câmara dos Deputados. Cf. SILVA, José Afonso. Curso de direito constitucional positivo. 11. ed. São Paulo: Malheiros, 1996, p. 698.
} 


\section{PODER JUDICIÁRIO NO ESTADO DE DIREITO}

O Poder Judiciário no Estado de Direito foi qualificado por Oswaldo Aranha Bandeira de Mello como o "oráculo da Constituição rígida"26. Celso Antônio Bandeira de Mello realizou uma extensão muito apropriada: o Judiciário é o "oráculo do Direito"27. A feliz expressão indica o papel dogmático do juiz: é o órgão habilitado a dar a última palavra, para o caso concreto, sobre a interpretação jurídica. Coerentemente, só a norma jurisdicional é dotada do atributo da coisa julgada ${ }^{28}$. A função típica do Poder Judiciário é exercer a jurisdição no sentido etimológico da palavra, ou seja, "dizer o Direito", estabelecer, de modo definitivo, para o caso concreto a interpretação jurídica correta.

Por meio da figura de linguagem denominada personificação ou prosopopeia, que consiste em atribuir qualidades humanas a seres inanimados ${ }^{29}$, suponha-se que o ordenamento jurídico brasileiro possua uma vontade. Quando essa vontade admite apenas uma única decisão ("x"), configura-se uma competência vinculada; quando admite duas ou mais decisões (" $x$ " ou " $y$ "), configura-se uma competência discricionária ${ }^{30}$. Descobrir a vontade do ordenamento jurídico é uma atividade eminentemente cognitiva, consistente na interpretação das normas vigentes ${ }^{31}$; escolher entre duas ou mais alternativas igualmente admitidas, com base em convicções subjetivas sobre a melhor forma de realizar o interesse público, é uma atividade eminentemente volitiva.

Feita essa distinção, é possível dar mais um passo na caracterização da função jurisdicional: trata-se de uma função cognitiva e não volitiva, pois cabe o magistrado, no exercício da função jurisdicional, descobrir, por meio da interpretação, a vontade do Direito; não realizar escolhas, estabelecendo, ele próprio, essa vontade. A título de

26 BANDEIRA DE MELLO, Oswaldo Aranha. A teoria das constituições rígidas. 2. ed. São Paulo: José Bushatsky, 1980, p. 89-93.

27 BANDEIRA DE MELLO, Celso Antônio. Juízo liminar: poder-dever de exercício do poder cautelar nessa matéria. Revista trimestral de direito público, São Paulo, n. 3, p. 106-116, 1993, p. 114; BANDEIRA DE MELLO, Celso Antônio. Mandado de segurança contra denegação ou concessão de liminar. Revista de direito administrativo e infraestrutura - RDAI, São Paulo, n. 11, ano 3, p. 441-449, out./dez. 2019, p. 442.

28 A coisa julgada não é um efeito da sentença, nem uma qualidade do efeito da sentença, é uma propriedade da norma jurídica que a torna imutável, indiscutível e inexpugnável como texto normativo. A coisa julgada torna imutável não propriamente o efeito da sentença, mas o enunciado linguístico da regra editada pela sentença. Cf. MARTINS, Ricardo Marcondes. Efeitos dos vícios do ato administrativo. São Paulo: Malheiros, 2008, p. 349-350.

29 Cf. GUIMARÃES, Hélio de Seixas; LESSA, Ana Cecília. Figuras de linguagem: teoria e prática. 14. ed. São Paulo: Atual, 2003, p. 54.

30 Sobre a competência discricionária, vide: MARTINS, Ricardo Marcondes. Teoria jurídica da liberdade. São Paulo: Contracorrente, 2015, p. 112 et seq.

31 Adota-se um conceito amplo de interpretação, abrangente do que parte da doutrina chama de "construção jurídica". Cf. MARTINS, Ricardo Marcondes. Teoria geral da interpretação jurídica: considerações críticas à obra de Black. Revista de Direito Administrativo e Infraestrutura (RDAI), São Paulo, ano 1, v. 3, p. 299-331, out./dez. 2017, p. 304-308. Aceita-se a teoria da interpretação criativa proposta por Ronald Dworkin, segundo a qual a interpretação tenta tornar o objeto o melhor possível (DWORKIN, Ronald. 0 império do direito. Tradução: Jefferson Luiz Camargo. 1. ed. 2. tir. São Paulo: Martins Fontes, 2003, p. 65). 
exemplo, suponha-se um pedido de antecipação de tutela. Haveria discricionariedade se, para o Direito, fosse, em um primeiro momento, válido tanto deferir a antecipação (" $x$ ") quanto indeferi-la (" $y$ "); admitidas as duas alternativas como juridicamente válidas, caberia ao agente competente, com base em sua vontade (ato volitivo), escolher entre uma alternativa e outra. O juiz, nesse caso, estaria habilitado a escolher, com base em seu íntimo, vale dizer, a partir de suas convicções sobre a melhor forma de realizar o Direito. É isso que ocorre, em geral, na nomeação de Ministros de Estado: quase sempre há dois ou mais interessados em ocupar o cargo que são considerados, do ponto de vista objetivo, igualmente aptos a bem exercer a função, de modo que será uma decisão jurídica válida tanto a escolha de um, como a escolha de outro, e o Direito elege como sua própria vontade a vontade do agente competente, definida tendo em vista, não seu livre-arbítrio, mas seus critérios subjetivos sobre a melhor forma de realizar o interesse público. Em relação à função jurisdicional, não é isso que ocorre. Retomando o exemplo da antecipação de tutela: não cabe ao magistrado escolher, mas interpretar; vale dizer, deve procurar descobrir qual a "vontade" do Direito, ou seja, descobrir se o sistema normativo vigente exige que seja deferida ou indeferida a liminar. Trata-se de apurar qual é a correta interpretação - ato cognitivo e não volitivo - competência vinculada e não discricionária.

Vislumbra-se apenas uma exceção a essa regra: o mandado de injunção, expressamente previsto no inciso LXXI do artigo $5^{\circ}$ da CF/88. Comumente, admitem-se duas ou mais formas de regulamentar um direito de modo a garantir seu exercício. Quando o Poder Legislativo ou o Poder Executivo não exercem a respectiva competência discricionária e não editam a norma abstrata necessária ao exercício do direito, cabe ao Poder Judiciário, por expressa norma constitucional, quando houver provocação, regulamentá-lo para o caso concreto. Apenas nesse caso admite-se o exercício de competência discricionária no exercício da função jurisdicional ${ }^{32}$.

32 Considera-se o mandado de injunção uma técnica de controle difuso de constitucionalidade, pois a regulamentação do direito dá-se para o caso concreto. Por isso, o Poder Judiciário, no mandado de injunção, não substitui o Legislador, realizando a disciplina no plano abstrato. Por décadas, o STF equiparou o mandado de injunção à ação direta de inconstitucionalidade por omissão, e se limitou ao apelo ao Legislador: oficiar o Parlamento, informando-Ihe da omissão inconstitucional e solicitando-Ihe suprimir a omissão. Em países em que a democracia é apenas formal, em que a cidadania é ainda incipiente, o apelo ao Legislador, cuja única sanção é a não reeleição, não possui eficácia fática, tornando-se um instituto inútil. A compreensão do STF, porém, violava de modo irrefutável o texto constitucional. A Corte corrigiu o equívoco no MI 712, no qual possibilitou aos servidores públicos o exercício do direito de greve (STF, MI 712, Rel. Min. Eros Grau, Pleno, j. 25.10.2007, DJe-206 Divulg. 30.10.2008, Public. 31.10.2008, Ement. v. 02339-03, p. 00384). Nesse caso, porém, o STF aceitou a impetração de mandado de injunção coletivo e disciplinou o direito, no plano abstrato, para todos os servidores. Ao fazê-lo, violou a separação de poderes. É constitucional o mandado de injunção coletivo desde que se tome o interesse coletivo em seu sentido técnico de interesse de um grupo, categoria ou classe de pessoas determinadas, vale dizer, de interesse referente a um número determinado ou determinável de pessoas. Assim, seria válida a regulamentação do direito para uma categoria de servidores, não para todos. Os Ministros Ricardo Lewandowski, Joaquim Barbosa e Marco Aurélio corretamente restringiram a decisão à categoria representada pelo Sindicato impetrante, mas foram vencidos. O parágrafo único do artigo 13 da Lei n 13.300/2016, ao admitir que a decisão atinja um número indeterminado de pessoas (interesse difuso), é 
O magistrado, oráculo do Direito, não pode ser parte do conflito que lhe é apresentado. Em busca de uma decisão justa ${ }^{33}$, o sistema normativo exige que o magistrado seja imparcial, no sentido de não ser parte. Imparcialidade vai além da impessoalidade: além do dever de não decidir tendo em vista interesses e afetos subjetivos, há o dever de neutralidade em relação à lide ${ }^{34}$. Como desdobramento dessa exigência, a jurisdição é inerte: faz-se necessária a provocação de outrem pela propositura de uma ação judicial ${ }^{35}$. O próprio magistrado não pode iniciar o processo, pois, do contrário, perderia sua imparcialidade; do mesmo modo, não pode ser testemunha.

Apesar de o juiz ser qualificado como oráculo do Direito, não se adota a teoria do realismo jurídico; vale dizer, não se restringe o Direito ao que o magistrado $\mathrm{diz}^{36}$. Considera-se, na Civil Law ${ }^{37}$, que o Direito é a interpretação correta dos textos normativos vigentes. O qualificativo é importante: acredita-se que haja interpretações corretas e incorretas, tendo em vista a observância ou não de certos postulados hermenêuticos ${ }^{38}$;

inconstitucional. Em sentido contrário: FONSECA, João Francisco. $\mathbf{O}$ processo do mandado de injunção. São Paulo: Saraiva, 2016, p. 175.

33 Decisão justa é a que realiza a ótima ponderação dos princípios, materiais e formais, incidentes. Cf. MARTINS, Ricardo Marcondes. Direito e justiça. In: PIRES, Luis Manuel Fonseca; MARTINS, Ricardo Marcondes. Um diálogo sobre a justiça. Belo Horizonte: Fórum, 2012, p. 68-70 e 76-77.

34 Vinculando a imparcialidade à neutralidade: SOUZA, Artur César de. A parcialidade positiva do juiz. São Paulo: Revista dos Tribunais, 2008, p. 32-33. Em sentido contrário, afirmando expressamente que imparcialidade não se confunde com neutralidade, e associando-a à impessoalidade: DINAMARCO, Cândido Rangel. Instituições de direito processual civil - v. I. São Paulo: Malheiros, 2001, § 80, p. 201. A associação da imparcialidade à impessoalidade é bastante difundida na doutrina administrativista. Por todos: ÁVILA, Ana Paula Oliveira. O princípio da impessoalidade da Administração Pública: para uma administração imparcial. Rio de Janeiro: Renovar, 2004, p. 107 et seq. Apesar de corrente, a orientação é equivocada. O Administrador Público, por definição, é parte dos conflitos, está envolvido psicologicamente com as políticas públicas que implementa, com os processos que instaura, com os fatos que testemunha. Apesar de atuar com parcialidade, deve ser impessoal, vale dizer, decidir como órgão e não como indivíduo, desvinculado de seus próprios interesses e de seus próprios afetos.

35 Por todos: CINTRA, Antonio Carlos de Araújo; GRINOVER, Ada Pellegrini; DINAMARCO, Cândido Rangel. Teoria geral do processo. 11 ed. São Paulo: Malheiros, 1995, p. 128-129.

36 Sobre o realismo, vide, por todos: OLIVECRONA, Karl. Linguagem jurídica e realidade. Tradução: Edson L. M. Bini. São Paulo: Quartier Latin, 2005, p. 24 et seq.

37 Sobre a Civil Law, também chamada de "sistema romano-germânico", vide, por todos: DAVID, René. Os grandes sistemas do direito contemporâneo. Tradução: Hermínio A. Carvalho. São Paulo: Martins Fontes, 2002, p. 35 et seq.

38 Segundo a Teoria do Legislador Racional, proposta por Carlos Santiago Nino, a interpretação jurídica exige pressupor que o Legislador seja: 1) único; 2) imperecível; 3) consciente; 4) onisciente; 5) operante; 6) justo; 7) coerente; 8) onicompreensivo; 9) preciso (SANTIAGO NINO, Carlos. Introdução à análise do direito. Tradução: Elza Maria Gasparotto. São Paulo: WMF Martins Fontes, 2015, p. 386-387). Segundo a Teoria da interpretação criativa, proposta por Ronald Dworkin, a interpretação jurídica é presidida por dois princípios de integridade política: um direcionado aos editores normativos - por metonímia, Dworkin se refere ao Legislador -, que impõe a eles tentar tornar o conjunto de normas um conjunto moralmente coerente; e outro direcionado aos aplicadores das normas - por metonímia, Dworkin se refere ao Juiz —, que impõe a eles tomar o conjunto normativo como respeitante a essa exigência, vale dizer, como, de fato, moralmente coerente (DWORKIN, Ronald. 0 império do direito. Tradução: Jefferson Luiz Camargo. 1. ed. 2. tir. São Paulo: Martins Fontes, 2003, p. 65). 
por conseguinte, a Hermenêutica Jurídica é uma atividade científica que tem por objeto indicar a interpretação correta ${ }^{39}$. Ocorre que o juiz, em sua atividade judicante, é fadado a errar, quer dizer, a não encontrar a interpretação "correta". Como bem elucidada Ronald Dwokin, só um juiz sobre-humano, por ele chamado de juiz-Hércules ${ }^{40}$, acertaria sempre, pois, para tanto, teria que conhecer todas as normas, todos os fatos e ter sempre a máxima sensibilidade para as questões humanas ${ }^{41}$. Um juiz real deve tentar, ao máximo, se aproximar do juiz-Hércules. Por mais que tente, é inquestionável: inevitavelmente errará na compreensão do Direito.

Por uma questão de necessidade, para a manutenção da paz social e concretização da segurança, o erro do Judiciário é assimilado pelo sistema normativo, para o caso concreto, como acerto. A razão disso é simples: regra geral, é mais injusto manter um conflito indefinidamente sem solução do que resolvê-lo de modo injusto ${ }^{42}$. Trata-se de uma regra de calibração ${ }^{43}$ : a decisão jurisdicional transitada em julgado é aceita como válida, ainda que cientificamente equivocada. Dito isso, três observações são necessárias.

Primeira: essa regra atua no controle difuso, mas não atua no controle concentrado. Por conseguinte, a coisa julgada no controle concentrado de constitucionalidade difere sensivelmente da coisa julgada no controle difuso. Se o STF declara inconstitucional uma lei que é constitucional, ela é retirada do mundo jurídico, mas nada impede que o Poder Legislativo edite, no dia seguinte, outra lei com igual conteúdo, reintroduzindo a questão no ordenamento jurídico ${ }^{44}$. Impugnada a validade dessa lei perante o STF, nada impede que a Corte reconheça seu erro e, dessa vez, considere-a válida. Ao revés, se a Corte declara a constitucionalidade de uma lei que é inconstitucional,

39 Cf. MARTINS, Ricardo Marcondes. Produção científica do direito administrativo. Revista Colunistas de Direito do Estado, n. 393, 22 abr. 2018. Disponível em: https://goo.gl/f2U4oC. Acesso em: 07 mar. 19.

40 DWORKIN, Ronald. O império do direito. Tradução: Jefferson Luiz Camargo. 1. ed. 2. tir. São Paulo: Martins Fontes, 2003, p. 295.

41 Como bem observa Carlos Ayres Britto, parafraseando Tobias Barreto, a decisão jurídica pressupõe um ato de pensar e um ato de sentir (BRITTO, Carlos Ayres. O humanismo como categoria constitucional. Belo Horizonte: Fórum, 2007, p. 75). Com efeito: interpretar o Direito exige sensibilidade para as questões humanas. Cf. MARTINS, Ricardo Marcondes. Direito e justiça. In: PIRES, Luis Manuel Fonseca; MARTINS, Ricardo Marcondes. Um diálogo sobre a justiça. Belo Horizonte: Fórum, 2012, p. 83-85.

42 Cf. MARTINS, Ricardo Marcondes. Direito e justiça. In: PIRES, Luis Manuel Fonseca; MARTINS, Ricardo Marcondes. Um diálogo sobre a justiça. Belo Horizonte: Fórum, 2012, p. 81-83.

43 Cf. FERRAZ JR., Tercio Sampaio. Teoria da norma jurídica. 4. ed. Rio de Janeiro: Forense, 2002, p. 131. Sobre o conceito de calibração: WATZLAWICK, Paul; BEAVIN, Janet Helmick; JACKSON, Don D. Pragmática da comunicação humana. Tradução: Álvaro Cabral. 21. ed. São Paulo: Cultrix, 2010, p. 132-133.

44 Por todos: BARROSO, Luís Roberto. 0 controle de constitucionalidade no direito brasileiro. São Paulo: Saraiva, 2004, p. 158-159. 
nada impede que a ação seja reproposta ${ }^{45}$. A ação pode ser ajuizada no dia seguinte ao julgamento, ainda que, em termos práticos - se não houve alteração da composição da Corte, e não transcorreu tempo razoável da decisão — , seja bem provável que o Tribunal decida da mesma forma. Perceba-se: como a regra de calibração não atua no plano abstrato, se a ADI foi julgada improcedente, ela pode ser reproposta, e a Corte, no reexame da questão, pode reconhecer o equívoco anterior e, dessa vez, declarar a inconstitucionalidade da norma.

Ronald Dworkin, com absoluta razão, afirma que a Ciência do Direito, e a comunidade em geral, não deve silenciar-se diante do erro do Judiciário ${ }^{46}$ : a crítica pode convencer os julgadores de que erraram e, no reexame das questões, eles podem acertar. Se, porém, os magistrados persistirem no erro, como observa também com absoluto acerto Dworkin, o fato não põe fim à verdade científica, pois "os juízes mais velhos irão morrer ou se aposentar"47. Se a crítica doutrinária for persistente, é bem provável que os magistrados mais novos, ao substituírem os que erraram, venham a acertar.

Segunda observação: a regra de calibração não é uma regra definitiva, mas prima facie. A depender da gravidade do erro do Judiciário, o sistema normativo não o assimila e permite a rediscussão da coisa julgada. Trata-se, nesse caso, da chamada coisa julgada inconstitucional ${ }^{48}$. Pontes de Miranda dá um ótimo exemplo: suponha-se uma sentença que decrete a escravidão; ainda que transcorra o prazo para a ação rescisória, nenhum jurista cogitaria fazê-la valer ${ }^{49}$. Na verdade, como bem explica Pontes de Miranda, há situações em que o Direito considera a sentença inexistente, insuscetível de ser considerada juridicamente uma sentença e, pois, de fazer coisa julgada. Nesses casos, rejeita-se a coisa julgada, descabendo falar em "rescisão da sentença", mas, sim, em declaração de sua inexistência. Com essa ressalva, há de se admitir: há certos erros que não são assimilados como acerto, não constituem coisa julgada propriamente dita.

Terceira observação: sempre que se fizer necessária a atuação da regra de calibração para validar o erro do magistrado, este perde prestígio. Se o magistrado interpreta corretamente o Direito e chega à decisão exigida pelo sistema, não há incidência

\footnotetext{
45 BARROSO, Luís Roberto. O controle de constitucionalidade no direito brasileiro. São Paulo: Saraiva, 2004, p. 152-153.

46 Cf. DWORKIN, Ronald. Levando os direitos a sério. Tradução: Nelson Boeira. São Paulo: Martins Fontes, 2002 , p. 321 et seq.

47 DWORKIN, Ronald. Levando os direitos a sério. Tradução: Nelson Boeira. São Paulo: Martins Fontes, 2002, p. 232.

48 Por todos: DINAMARCO, Cândido Rangel. Relativizar a coisa julgada material. In: NASCIMENTO, Carlos Valder do. (coord.). Coisa julgada inconstitucional. 2. ed. Rio de Janeiro: América Jurídica, 2002. p. 33-76.

49 PONTES DE MIRANDA, Francisco Cavalcanti. Tratado da ação rescisória. Campinas: Bookseller, 1998, §41, p. 449; PONTES DE MIRANDA, Francisco Cavalcanti. Tratado das ações - v. I. Campinas: Bookseller, 1998, §32, p. 171.
} 
da regra de calibração: a validade da norma editada por ele é extraída diretamente da Constituição, e não indiretamente desta, quer dizer, e não da regra de calibração. Porém, como todo ser humano, o juiz está condenado ao erro, à falha, ou seja, a interpretar mal o ordenamento e a não chegar à "vontade" do sistema jurídico. Se isso ocorre, pela regra de calibração, sua decisão é considerada como se fosse a correta, sendo acatada pelo sistema. Por óbvio, o erro reiterado do magistrado, a necessidade de constante calibração para validar sua decisão, retira-lhe o prestígio. Assim, Tribunais Constituintes que erram muito possuem pouco prestígio na comunidade jurídica.

Com as ressalvas aqui estabelecidas, retoma-se: o magistrado é o oráculo do Direito, mas isso não significa que ele jamais erre na interpretação jurídica; ao revés, como ser humano está fadado a errar, mas seu erro é assimilado pelo sistema normativo. Ele é titular da competência para pôr um fim ao conflito, para dizer definitivamente o direito para o conflito; é, em suma, o agente habilitado e qualificado pelo sistema para ser o oráculo do Direito. Compreendida a função jurisdicional, retoma-se o tema central deste estudo: é possível considerar o Judiciário uma fonte do estado de exceção?

\section{ESTADO DE EXCEÇÃO ILÍCITO}

Os erros do Judiciário, regra geral, não são suficientes para estabelecer um estado de exceção. Nos termos explicados, existe uma regra de calibração no sistema normativo por força da qual os erros cometidos no exercício da função jurisdicional são, quando a questão transita em julgado, assimilados como acertos. Essa regra, porém, não é absoluta: a calibração não funciona quando os equívocos do Poder Judiciário não decorrem apenas de um equívoco de interpretação, mas de um problema institucional. São justamente essas hipóteses que configuram um estado de exceção ilícito.

A título de exemplo, menciona-se a atuação do Poder Judiciário no período do Regime Militar, que vigorou de 1964 a 1985 $5^{50}$. O jornalista Felipe Recondo realizou um detalhado estudo da atuação do Supremo Tribunal Federal nesse período ${ }^{51}$. Em 1964, o STF era composto pelos Ministros: 1) Antonio Carlos Lafayette de Andrada; 2) Alvaro Moutinho Ribeiro da Costa; 3) Hahnemann Guimarães; 4) Luiz Gallotti; 5) Candido Motta Filho; 6) Antônio Martins Vilas Boas; 7) Antonio Gonçalves de Oliveira; 8) Victor Nunes Leal; 9) Pedro Rodovalho Marcondes Chaves; 10) Hermes Lima; 11) e Evandro Cavalcanti Lins e Silva.

50 Por todos: FAUSTO, Boris. História do Brasil. 5. ed. São Paulo: Editora da Universidade de São Paulo, 1997, p. 463-515.

51 RECONDO, Felipe. Tanques e togas: o STF e a ditadura militar. São Paulo: Companhia das Letras, 2018, p. $235-253$. 
Os militares desejaram ter sempre maioria na Corte. A solução, de início, foi aumentar o número de magistrados: em 27 de outubro de 1965, por meio do Ato Institucional n. 02, Castello Branco criou mais cinco vagas, para supostamente ter sempre a maioria, e nomeou: 1) Adalício Coelho Nogueira; 2) José Eduardo do Prado Kelly; 3 ) Oswaldo Trigueiro de Albuquerque Mello; 4) Aliomar de Andrade Baleeiro; 5) e Carlos Medeiros Silva ${ }^{52}$.

Castello Branco também nomeou: em 22 de fevereiro de 1967, Djaci Alves Falcão para a vaga de Vilas Boas; em 02 de março de 167, Adaucto Lucio Cardoso para a vaga de Ribeiro da Costa. Seu sucessor, Costa e Silva, nomeou: em 07 de junho de 1967, Raphael de Barros Monteiro para a vaga de Pedro Chaves; em 18 de outubro de 1967, Themistocles Brandão Cavalcanti para a vaga de Hahnemann Guimarães e Moacyr Amaral Santos para a vaga de Candido Motta.

A mudança da composição da Corte não foi suficiente para satisfazer os militares. Sobreveio o Ato institucional n. 05, de 13 de dezembro de 1968, editado por Costa e Silva, por meio do qual foram aposentados compulsoriamente os Ministros Evandro Cavalcanti Lins e Silva, Hermes Lima e Victor Nunes Leal. Os dois primeiros haviam sido nomeados por João Goulart e o último por Juscelino Kubitschek. Em 03 de fevereiro de 1969 aposentaram-se Antonio Gonçalves de Oliveira e Antonio Carlos Lafayette de Andrada, provável razão por não terem sido cassados ${ }^{53}$. Com as aposentadorias compulsórias e "voluntárias", os militares tinham, então, nomeado todos os ministros do STF. Costa e Silva extinguiu por meio do Ato Institucional n. 06, de 06 de janeiro de 1969, as quatro vagas, não mais necessárias, criadas pelo Al n. 02.

O quadro é suficiente para indicar a situação da época: os Ministros do STF não possuíam mínima autonomia, pois, se descontentassem os militares, poderiam ser cassados. O período ainda é um tabu na história do país, mas, considerando o número de desaparecidos políticos, e os testemunhos sobre prisões arbitrárias, execuções e torturas, havia um risco concreto, para quem contrariasse o regime, de ser preso e/ ou morto ${ }^{54}$. $\mathrm{O}$ estudo de Felipe Recondo, muitíssimo bem fundamentado, baseado em

52 RECONDO, Felipe. Tanques e togas: o STF e a ditadura militar. São Paulo: Companhia das Letras, 2018, p. $102-123$.

53 RECONDO, Felipe. Tanques e togas: o STF e a ditadura militar. São Paulo: Companhia das Letras, 2018, p. 124-185.

54 Sobre o tema, por todos: RELATÓRIO da Comissão Nacional da Verdade. 10 dez. 2014. Disponível em: http:// cnv.memoriasreveladas.gov.br. Acesso em: 13 mar. 19; RELATÓRIO da Comissão da Verdade da Prefeitura de São Paulo. 14 dez. 2016. Disponível em: https://www.prefeitura.sp.gov.br/cidade/secretarias/direitos_humanos/ comissao_da_memoria_e_verdade/noticias/?p=227198. Acesso em: 13 mar. 19. Destaca-se, como paradigma, o caso de Aurora Maria Nascimento Furtado, cujo cadáver foi encontrado com mordidas pelo corpo, bicos dos seios cortados, fratura do braço exposta, um olho saltado e o crânio afundado. É o que se extrai do relato da advogada Eny Moreira in OS ADVOGADOS contra a ditadura. Direção, roteiro e texto: Silvio Tendler. Produção: Maycon Almeida, 2014. Disponível em http://caliban.com.br/filmografia_/os-advogados-contra-a-ditadura/. Acesso em: 13 mar. 19. O STF considerou que todos os crimes cometidos pelos militares durante o período foram objeto da anistia estabelecida na Lei Federal 6.683/79, sem que isso importe violação da Constituição 
relatos dos próprios Ministros, publicações da época e entrevistas realizadas pelo autor, evidencia que os votos eram dados com o temor, bastante concreto, de represálias.

Quando se afasta um julgador por discordar de suas posições e se nomeia outro, este se apresenta, não como julgador, mas como longa manus do ditador. Se, por um lado, não havia para os Ministros nomeados pelos Presidentes da República anteriores ao Regime Militar condições institucionais para o exercício jurisdicional, por outro, os Ministros nomeados pelos militares não possuíam, em decorrência de sua vinculação com o nomeante, tendo em vista as particularidades do regime, a isenção requerida pela função.

Nesse cenário, não vigora o Estado de Direito, mas, sim, uma situação geral de absoluta hipocrisia, um "faz de conta", apenas uma aparência de exercício jurisdicional. Em casos como esse, de falência institucional, o Estado de Direito cessa e se instaura um verdadeiro estado de exceção ilícito. ${ }^{55}$ Não há incidência da regra de calibração, porque o magistrado não atua em um cenário de isenção que lhe possibilite buscar, com base em suas convicções exegéticas, a interpretação correta do ordenamento vigente. A regra de calibração só atua quando as condições institucionais necessárias para o exercício da jurisdição estão presentes.

Por fim, nem todos os Ministros que foram nomeados pelos militares, é mister reconhecer, limitaram-se a ser longa manus dos ditadores. O Movimento Democrático Brasileiro - MDB - solicitou ao então Procurador Geral da República - PGR - que impugnasse a constitucionalidade do Decreto-lei no 1.077/70, editado por Garrastazu Médici, por meio do qual submeteram-se todas as publicações à prévia censura em prol da moral e bons costumes. Na época, o PGR era nomeado pelo Presidente da República e passível de exoneração ad nutum. A CF/1969 (formalmente Emenda Constitucional no 01 à CF/1967) previa que apenas o PGR era legitimado para propositura de ADI (art. 119, I, "I"). Xavier de Albuquerque, então PGR, fiel aos interesses de seu nomeante, recusou a representação. O MDB propôs, então, reclamação ao STF, sob o forte argumento de que, se coubesse ao PGR a última palavra, seria este o verdadeiro guardião da Constituição e não o STF. Todos os Ministros, com exceção de Adaucto Lúcio Cardoso, julgaram a

(STF, ADPF 153, Rel. Min. Eros Grau, Pleno, j. 29.04.2010, DJe-145, divulg. 05.08.10, public. 06.08.10). Posteriormente ao julgamento, o Brasil foi condenado pela Corte Interamericana de Direitos Humanos no caso Gomes Lund e outros ("Guerrilha do Araguaia") vs Brasil - sentença de 24.11.2010. Cf. MAZZUOLI, Valerio de Oliveira. Direitos humanos na jurisprudência internacional: sentenças, opiniões consultivas, decisões e relatórios internacionais. Rio de Janeiro: Forense, 2019, p. 587-595; MAZZUOLI, Valerio de Oliveira; GOMES, Luiz Flavio. Crimes da ditadura militar e o "Caso Araguaia": aplicação do direito internacional dos direitos humanos pelos juízes e tribunais brasileiros. São Paulo: Revista dos Tribunais, 2011, p. 49-72. É difícil acreditar que algum jurista considere hoje que os crimes cometidos contra a Aurora foram, de fato, objeto de anistia. É o que basta para justificar a assertiva: a questão é, ainda, um tabu.

55 Sobre as relações entre Estado de Direito e estado de exceção, ver: LEAL, Rogério Gesta. Sociedade de riscos e estado de exceção: encruzilhadas em labirintos. A\&C - Revista de Direito Administrativo \& Constitucional, Belo Horizonte, ano 19, n. 75, p. 179-193, jan./mar. 2019. 
reclamação improcedente ${ }^{56}$. Lúcio Cardoso foi, conforme já informado, nomeado por Castello Branco, mas, apesar disso, foi o responsável por um dos momentos mais marcantes do STF. No dia do julgamento, ao ouvir os votos dos colegas, deixou o plenário e nunca mais voltou à Corte ${ }^{57}$. Tornou-se o maior símbolo de resistência à falência institucional do Supremo Tribunal Federal.

\section{ATIVISMO JUDICIAL}

Fixados alguns contornos conceituais do exercício da função jurisdicional e do estado de exceção ilícito, faz-se necessário aprofundar um pouco mais o exame da atuação jurisdicional no Estado de Direito. O papel do Poder Judiciário foi profundamente revisto com a evolução do constitucionalismo: a perspectiva legalista do Poder Judiciário nada tem a ver com a perspectiva neoconstitucionalista. É corrente a indicação do "ativismo judicial" como fonte da exceção. Contudo, a palavra "ativismo" é problemática: muitas vezes ela é utilizada por oposição a essa evolução. Daí o problema: sob a ótica neoconstitucional há ativismo ilícito ensejador do estado de exceção? 0 tema exige exame cuidadoso.

O legalismo esteve na aurora do constitucionalismo ${ }^{58}$. Como os magistrados, na época, eram livremente nomeados pelos nobres - e estes não eram bem vistos pelos revolucionários franceses, tanto que boa parte deles foi guilhotinada - , é natural supor que os revolucionários não gostavam dos magistrados e tentaram a todo custo diminuir seu poder ${ }^{59}$. Como a Revolução Francesa inspirou-se em Rousseau, que considerava a vontade geral infalível ${ }^{60}$, atribuiu um poder quase absoluto ao Parlamento. Consagrou-se o entendimento de que o magistrado era, na expressão de Montesquieu, apenas uma boca que pronuncia as palavras da lei ${ }^{61}$. Daí o chamado referendo legislativo: se tivesse dúvida sobre a interpretação, o magistrado deveria suspender o julgamento e solicitar ao Legislativo que a afastasse ${ }^{62}$. Nesse cenário, se o Poder Judiciário

56 STF, Rcl. 849, Rel. Min. Adalício Nogueira, Pleno, j. 10.03.1971, DJ 13.12.1971, p. 7096.

57 RECONDO, Felipe. Tanques e togas: o STF e a ditadura militar. São Paulo: Companhia das Letras, 2018, p. 204-233.

58 O legalismo foi adotado pela escola da exegese, cujas características são didaticamente apresentadas por: BOBBIO, Norberto. $O$ positivismo jurídico: lições de filosofia do Direito. Tradução e notas: Márcio Pugliesi et al. São Paulo: Ícone, 1995, p. 84-89.

59 Sobre o período, por todos: MOTA, Carlos Guilherme. A revolução francesa. 2. ed. São Paulo: Perspectiva, 2013, p. 72 et seq.

60 ROUSSEAU, Jean-Jacques. O contrato social. Tradução: Antônio de P. Machado. Rio de Janeiro: Ediouro, [19-], p. 46-47.

61 MONTESQUIEU. Do espírito das leis. Tradução: Fernando Henrique Cardoso e Leôncio Martins Rodrigues. 2. ed. São Paulo: Abril Cultural, 1979, Livro XII, Capítulo VI, p. 152.

62 Cf. GUASTINI, Riccardo. Las fuentes del derecho: fundamentos teóricos. Tradução: César E. Moreno More e Luis Cárdenas Rodríguez. Lima: Raguel, 2016, p. 250. 
se afastasse da literalidade dos textos normativos, violava a separação de Poderes e praticava um autêntico "ativismo".

Essa crença cega no Legislador está, hoje, absolutamente sepultada. O Estado nazista fundamentou-se em leis previamente aprovadas pelo Parlamento ${ }^{63}$. Com a derrocada do regime, os nazistas defenderam-se sob o argumento de que aplicaram a lei vigente, o que gerou uma crise de paradigma científico ${ }^{64}$. Em reação a essa crise, o Direito passou a ser considerado, não apenas um conjunto de normas jurídicas, mas uma "ordem objetiva de valores"65. Aplicar o Direito pressupõe subsumir os fatos às regras, mas também sopesar os valores relacionados ao caso. Esta é a premissa fundamental do chamado "neoconstitucionalismo"66: a edição de qualquer norma jurídica pressupõe uma ponderação de princípios. Se os europeus tiveram razões para desconfiar do Parlamento, e não considerar a democracia um valor absoluto ${ }^{67}$, mais razões têm os brasileiros cuja democracia é apenas formal ${ }^{68}$.

Nesse cenário, o exercício da função jurisdicional muda substancialmente ${ }^{69}$. Exercer a função jurisdicional não é mais aceitar passivamente as decisões do Legislador. A título de exemplo: na era do legalismo, se a lei autorizava a venda de um imóvel da Administração Pública, a venda seria válida; bastava o Legislador autorizar. Tudo mudou: a lei precisa ser constitucional e, para tanto, deve haver razões de interesse público que justifiquem a venda. A arbitrária dilapidação do patrimônio do povo viola a Constituição ${ }^{70}$. Outro exemplo: para tipificar uma conduta como crime não basta a vontade do Legislador; a tipificação só é válida na medida em que proteja um bem jurídico e essa proteção seja proporcional à restrição da liberdade imposta pela pena ${ }^{71}$.

63 Um excelente retrato histórico é apresentado por RIGAUX, François. A lei dos juízes. Tradução: Edmir Missio. 1. ed. 2. tir. São Paulo: Martins Fontes, 2000, p. 107 et seq.

64 A situação é retratada exemplarmente por ARENDT, Hannah. Eichmann em Jerusalém. Tradução: José Rubens Siqueira. 12. reimpr. São Paulo: Companhia das Letras, 1999, p. 152 et seq.

65 A expressão foi utilizada pelo Tribunal Constitucional Alemão no caso Lüth (BVerfGE 7, 198). Sobre ele, vide: SCHWABE, Jürgen. Cinquenta anos de jurisprudência do tribunal constitucional federal alemão. Tradução Beatriz Hennig et al. Montevideo: Konrad-Adenauer-Stiftung, 2005, p. 381-394; MARTINS, Ricardo Marcondes. Abuso de direito e a constitucionalização do direito privado. São Paulo: Malheiros, 2010, p. 75 et seq.

66 Sobre o neoconstitucionalismo, vide: MARTINS, Ricardo Marcondes. Neoconstitucionalismo: perscrutação sobre a pertinência do prefixo. Revista Internacional de Direito Público (RIDP), Belo Horizonte, ano 2, n. 3, p. 9-37, jul./dez. 2017.

67 Por todos: ALEXY, Robert. Constitucionalismo discursivo. Tradução: Luís Afonso Heck. Porto Alegre: Livraria do Advogado, 2007, p. 52-54.

68 Nunca houve democracia material no Brasil. Cf. BANDEIRA DE MELLO, Celso Antônio. A democracia e suas dificuldades contemporâneas. Revista Trimestral de Direito Público, São Paulo, n. 15, p. 100-111, 1996.

69 A mudança do papel do juiz e da importância do legislador é magistralmente apresentada por: ZAGREBELSKY, Gustavo. El derecho dúctil: ley, derecho, justicia. Tradução: Marina Gascón. Madri: Trotta, 2005.

70 Cf. MARTINS, Ricardo Marcondes. Efeitos dos vícios do ato administrativo. São Paulo: Malheiros, 2008, p. 75.

71 Cf. MARTINS, Ricardo Marcondes. Teoria jurídica da liberdade. São Paulo: Contracorrente, 2015, p. 26-27. A teoria penal da proteção do bem jurídico foi magnificamente desenvolvida por ROXIN, Claus. A proteção de 
Longe de ser apenas uma boca nula, que pronuncia as palavras da lei, cabe ao magistrado verificar se a ponderação realizada pelo Legislador no plano abstrato é válida, vale dizer, se a restrição valorativa por ele imposta é proporcional; sendo válida no plano abstrato, deve verificar se a validade se mantém no plano concreto. É bem possível que a lei seja constitucional no plano abstrato, mas sua aplicação seja inconstitucional no plano concreto.

Adotada essa compreensão do fenômeno jurídico, toda política se juridiciza: passa a ser exercício de competência discricionária. Nem o Legislador nem a Administração possuem liberdade, mas discricionariedade. Há situações em que o Direito aceita duas ou mais alternativas como igualmente válidas, imputando a escolha ao agente competente; é possível, contudo, que o Direito exija uma solução apenas, de modo que a competência seja vinculada ${ }^{72}$. É possível que haja discricionariedade e o agente escoIha alternativa não admitida: o Direito admite "a" ou "b" e o agente escolhe "c". Cabe ao Judiciário, quando provocado, verificar se a escolha realizada pelo Legislador ou pela Administração Pública era admitida pelo Direito, vale dizer, se havia, de fato, discricionariedade e, havendo, se o agente competente escolheu uma alternativa admissível. Toda atuação estatal submete-se, então, à possibilidade de denso controle jurisdicional.

Ao ter que examinar cada decisão política, há um risco de ocorrer a "desneutralização política do juiz"73: o magistrado deixa de buscar a vontade do ordenamento e passa a realizar a política. Isso ocorre quando ele não respeita a competência discricionária, mas a viola, tomando para si a prerrogativa de escolher. Enquanto o magistrado busca a "vontade do ordenamento jurídico", não há que se falar de ativismo; quando, porém, passa a não mais interpretar, mas escolher, configura-se o ativismo. Diferenciar uma situação de outra não é tarefa fácil. ${ }^{74}$

Para evidenciar essa dificuldade menciona-se a teoria do estado de coisas inconstitucional - ECl, pioneiramente desenvolvida pela Corte Constitucional Colombiana $^{75}$. Impugnou-se no STF a omissão estatal, de todos os Poderes da República, em

bens jurídicos como função do Direito Penal. Tradução: André Luís Callegari e Nereu José Giacomolli. Porto Alegre: Livraria do Advogado, 2006.

72 Sobre a vinculação e a discricionariedade, vide MARTINS, Ricardo Marcondes. Teoria jurídica da liberdade. São Paulo: Contracorrente, 2015, p. 106 et seq.

73 A expressão é de FERRAZ JR., Tercio Sampaio. Argumentação jurídica. Barueri: Manole, 2014.

74 Sobre a temática do ativismo judicial, vide: LEAL, Rogério Gesta. Riscos e possibilidades do ativismo judicial na democracia. A\&C - Revista de Direito Administrativo \& Constitucional, Belo Horizonte, ano 21, n. 83, p. 119-135, jan./mar. 2021; FIGUEIREDO, Marcelo. O ativismo do Supremo Tribunal Federal e a ausência de critérios claros em matéria de direitos fundamentais. A\&C - Revista de Direito Administrativo \& Constitucional, Belo Horizonte, ano 18, n. 74, p. 97-123, out./dez. 2018; ARAÚJO, Luiz Fernando Diniz. O ativismo judicial e constrangimentos a posteriori. Revista de Investigações Constitucionais, Curitiba, vol. 5, n. 1, p. 129-150, jan./abr. 2018.

75 Sobre ela, vide a magnífica monografia de CAMPOS, Carlos Alexandre de Azevedo. Estado de coisas inconstitucional. Salvador: Juspoivm, 2016. Ver, ainda: MACHADO, Maira Rocha. Quando o estado de coisas é inconstitucional: sobre o lugar do Poder Judiciário no problema carcerário. Revista de Investigações 
relação à situação carcerária. A CPI realizada na Câmara dos Deputados, em 2009, sobre a situação dos presídios no Brasil evidenciou algo que a comunidade jurídica já sabia há um bom tempo: o sistema carcerário brasileiro viola a dignidade da pessoa humana de modo drástico ${ }^{76}$. Os problemas são múltiplos: uma superlotação aviltante, celas sem estrutura hidráulica, sanitária, elétrica, sem mínimas condições de higiene, presos sem receber material de higiene básica e alimentação adequada. O PSOL impugnou essa omissão estatal por meio da ADPF n. 347.

Em 09 de setembro de 2015 a Corte proferiu um julgamento histórico: reconheceu a configuração do ECl e deferiu parcialmente a medida cautelar para determinar a todos os magistrados que passem a realizar audiências de custódia, à União que efetue o descontingenciamento do Fundo Penitenciário Nacional e à União e aos Estados que encaminhem à Corte informações sobre o atual sistema prisional ${ }^{77}$. Contudo, todos os demais pedidos da cautelar foram indeferidos ou considerados prejudicados. Apesar de ser considerada um avanço, a decisão ficou muito aquém do que deveria: a Corte reconheceu a verdade da afirmação feita na inicial de que parte significativa dos detentos do país já cumprira a pena, mas indeferiu o pedido de realização de mutirões para resolver o problema. Se o STF determinasse efetivas medidas concretas para resolver o problema carcerário no Brasil, pondo fim à desídia governamental, certamente seria acusado de "ativista" e, pois, de violador da separação de poderes

Retoma-se: muitas vezes, qualifica-se de "ativismo" a correta compreensão do ordenamento pelo Poder Judiciário, a compreensão de que o Direito não se esgota na literalidade dos textos normativos, de que a maioria das proibições e obrigações jurídicas estão implícitas. É bem conhecido o exemplo de Recasens Siches sobre uma norma que proíbe a entrada de cães em uma estação ferroviária e a sua indagação sobre a proibição da entrada de $\operatorname{ursos}^{78}$. A doutrina tradicional, presa ao legalismo e à falsa percepção de que o direito se restringe às normas extraídas da literalidade dos textos legais, considera que aí haveria uma lacuna, a ser integrada pelo magistrado por meio da analogia: se há norma proibindo a entrada de cães em prol da segurança dos usuários da estação, cabe criar outra norma que proíba a entrada de ursos. Essa posição, apesar de difundida, consiste em um grave erro de compreensão do fenômeno jurídico. Se a proibição da entrada de cães é válida, existe implicitamente no sistema normativo

Constitucionais, Curitiba, vol. 7, n. 2, p. 631-664, maio/ago. 2020; e LIMA, Gabriela Eulalio de; ANDRADE, Sinara Lacerda. O estado de coisas inconstitucional e a crise financeira à luz da economia compartilhada. Revista de Direito Econômico e Socioambiental, Curitiba v. 11, n. 3, p. 193-212, set./dez. 2020.

76 Sobre a situação carcerária brasileira, por todos: CAMPOS, Carlos Alexandre de Azevedo. Estado de coisas inconstitucional. Salvador: Juspoivm, 2016, p. 264 a 276.

77 STF, ADPF 347 MC, Relator Min. Marco Aurélio, Tribunal Pleno, julgado em 09.09.2015.

78 SICHES, Luis Recasens. Introducción al estudio del derecho. 15. ed. México: Porrúa, 2006, p. 217. 
a proibição da entrada de ursos ${ }^{79}$. O magistrado não cria essa proibição, mas a "descobre" no sistema. A analogia não é uma técnica de criação de novas normas, mas de revelação de normas implícitas já existentes. Pois bem: não é ativismo revelar as normas implícitas; não é ativismo impor os deveres que já se extraem do ordenamento jurídico.

O ativismo se configura quando o Poder Judiciário abdica de apurar quais são as normas existentes no ordenamento jurídico, qual o sentido e o alcance delas e quais são válidas, e passa, ele próprio, a criar normas ou a impor sua violação. Deixa de realizar uma atividade cognitiva de entender corretamente o Direito vigente e passa a exercer uma atividade puramente volitiva. Abusa do exercício funcional para, com base nele, criar obrigações e permissões arbitrárias. Prende alguém, não porque foi provado que este cometeu algum crime previsto na legislação; prende por razões políticas ou de foro íntimo. Em suma: quando o Poder Judiciário deixa de ser intérprete, configura-se o ativismo judicial. Insiste-se, porém, no problema: não é fácil saber quando isso ocorre. Como diz Friedrich Müller, boa parte do Direito está implícita nos textos normativos ${ }^{80}$. A compreensão de quais são as normas existentes, qual o sentido delas, e quais são válidas é uma atividade envolta em acirradas controvérsias. O magistrado não é ativista apenas por divergir do jurisdicionado na compreensão do Direito.

Feitas essas ressalvas, conclui-se: o ativismo judicial, mesmo se caracterizado, não é suficiente para gerar um estado de exceção ilícito. O erro decorrente do ativismo é, dogmaticamente, regra geral, equiparado ao erro de interpretação. Ele só será causador do estado de exceção quando não se tratar de um abuso pontual, mas de uma falência institucional do Poder Judiciário.

\section{RESISTÊNCIA NO ESTADO DE DIREITO}

Para terminar este estudo, faz-se necessário examinar, tendo em vista as premissas inicialmente fixadas, a reação ao estado de exceção ilícito. Do ponto de vista dogmático, há de se diferenciar duas situações: a execução administrativa de uma norma existente e a execução administrativa de uma norma inexistente. Adotada a teoria dos planos jurídicos, se cumpridas certas exigências (elementos e pressupostos de existência), a norma existirá ${ }^{81}$. É possível, porém, que o Estado resolva executar uma norma que

79 Cf. MARTINS, Ricardo Marcondes. Teoria geral da interpretação jurídica: considerações críticas à obra de Black. Revista de Direito Administrativo e Infraestrutura (RDAI), São Paulo, ano 1, v. 3, p. 304.

80 Friedrich Müller vale-se de uma metáfora: imagine-se um enorme iceberg submerso nas águas do mar, em que apenas a ponta encontra-se emersa; o teor literal dos textos normativos é apenas a "ponta do iceberg" (MÜLLER, Friedrich. Métodos de trabalho do direito constitucional. 2. ed. Tradução: Peter Naumann. São Paulo: Max Limonad, 2000, p. 53).

81 Sobre a teoria dos planos jurídicos aplicada ao ato administrativo, vide: MARTINS, Ricardo Marcondes. Efeitos dos vícios do ato administrativo. São Paulo: Malheiros, 2008, p. 121 et seq. Para um resumo, vide: MARTINS, Ricardo Marcondes. Três planos da norma jurídica. Revista Colunistas de Direito do Estado, n. 238, 19 ago. 2016. Disponível em: http://goo.gl/HuK5bc. Acesso em: 15 mar. 19. 
não existe como norma no mundo jurídico, ou por falta de elementos (não possui um conteúdo normativo ou não possui forma jurídica, vale dizer, não foi exteriorizada) ou por falta dos pressupostos de existência (objeto - pessoa ou coisa a que o conteúdo se refere - , habilitação para editar a norma, mínimo de eficácia social, não concretização de intolerável injustiça). Diante da execução de um ato administrativo inexistente, configura-se o direito de resistência ativa: o administrado tem o direito subjetivo de reagir manu militare contra a execução ${ }^{82}$.

Se o ato existe, pode ser válido ou inválido. Caso se pretenda executar um ato inválido, o administrado não possui direito de resistência ativa, mas, sim, direito de resistência passiva: se o ato impõe uma obrigação ao administrado, dando prioridade ao cumprimento voluntário, ele pode descumpri-la; se for reconhecida a invalidade, não será sancionado pelo descumprimento ${ }^{83}$. Se a Administração pretender executar um ato inválido, caberá ao administrado apenas impugnar a execução na instância administrativa e/ou na instância jurisdicional. Se o órgão estatal competente não reconhecer a invalidade, não há direito de resistência.

Fixaram-se os conceitos de resistência ativa e passiva tendo em vista o exercício da função administrativa. Em relação à função jurisdicional, há um problema dogmático: conforme dantes explicado, o sistema normativo habilita o Poder Judiciário a dizer o Direito (jurisdictio). Quem dirá a última palavra sobre a existência ou inexistência jurídica é o Poder Judiciário. Noutras palavras, se ele reconhecer que o ato existe, ainda que cientificamente não exista, o Direito assimilará o erro como acerto: juridicamente existirá e não haverá direito de resistência ativa. Se considerar que o ato é válido, ainda que cientificamente seja inválido, da mesma forma, não haverá direito de resistência passiva, pois o Direito assimilará o erro como acerto. Se o jurisdicionado discorda da decisão judicial, caberá impugná-la por meio de recursos e ações judiciais previstas no sistema normativo. Com o trânsito em julgado, do ponto de vista dogmático, nada restará a não ser sujeitar-se à decisão.

O descumprimento do Direito por motivo político - não pela intenção propriamente de violar a norma, mas por não aceitar sua legitimidade — é assumido pelo Direito como simples descumprimento ${ }^{84}$. Em termos técnicos: a desconfirmação do poder estatal é desconfirmada, considerando-a uma negação. A negativa do poder

\footnotetext{
82 Cf. BANDEIRA DE MELLO, Celso Antônio. Curso de direito administrativo. 33. ed. São Paulo: Malheiros, 2016, p. 498; MARTINS, Ricardo Marcondes. Efeitos dos vícios do ato administrativo. São Paulo: Malheiros, 2008, p. 550-553 e 655-659.

83 Cf. BANDEIRA DE MELLO, Celso Antônio. Curso de direito administrativo. 33. ed. São Paulo: Malheiros, 2016, p. 498; MARTINS, Ricardo Marcondes. Efeitos dos vícios do ato administrativo. São Paulo: Malheiros, 2008, p. 550-553 e 655-659.

84 Cf. MARTINS, Ricardo Marcondes. Justiça deôntica. In: PIRES, Luis Manuel Fonseca; MARTINS, Ricardo Marcondes. Um diálogo sobre a justiça. Belo Horizonte: Fórum, 2012, p. 172-179.
} 
confirma o exercício do poder; a desconfirmação do poder destrói o poder ${ }^{85}$. Por isso, o poder sempre desconfirma a desconfirmação, tomando-a como negação ${ }^{86}$. Ainda que se descumpra o Direito por considerá-lo ilegítimo, os órgãos estatais tomarão o descumprimento como simples violação da norma. Não existe, por isso, atuação política autônoma dentro do Estado de Direito. Quem se volta contra o poder político, dentro do sistema, atua ilicitamente e deverá responder pela ilicitude. Essa atuação política só se legitima fora do Estado de Direito: caso os insurgentes consigam promover um golpe, derrubar o governo e dar efetividade a uma nova Constituição, darão início a uma nova ordem jurídica.

Em certas hipóteses excepcionais, de erros judiciais manifestos, mesmo do ponto de vista dogmático, considera-se legítimo o descumprimento. Um bom exemplo é a regra extraída do artigo 15 do Decreto-lei no 3.365/41, segundo a qual basta a Administração depositar o valor previsto na planta do IPTU para obter a imissão na posse do imóvel que é objeto da ação de desapropriação. A base de cálculo do IPTU é o valor venal do bem, vale dizer, seu valor de mercado ${ }^{87}$. Contudo, como a apuração desse valor para cada imóvel da cidade é impossível, a Administração efetua uma estimativa, regra geral para baixo. Logo, na prática, a planta de valores do IPTU raramente indica o valor venal; pelo contrário, indica um valor bem abaixo do valor de mercado. Suponhamos que um imóvel valha um milhão de reais, e esteja registrado na planta do IPTU como valendo cem mil reais. Pelo texto normativo, se o Poder Público depositar em juízo cem mil, pode obter a imissão na posse e iniciar a realização da obra pública. O que diz o STF? Os Ministros afirmam que nada há de errado nisso, pois o proprietário só perderá sua propriedade quando do registro da carta de adjudicação no Cartório de Imóveis, que ocorrerá ao final do processo (Súmula 652). O direito à prévia e justa indenização, dizem, só é garantido em relação à perda da propriedade. Na prática: o proprietário é retirado de sua casa, ela é demolida, constrói-se uma estrada sobre ela, e o proprietário fica com uma ínfima percentagem do valor de sua propriedade até que, décadas depois, a Administração pague o valor integral do precatório.

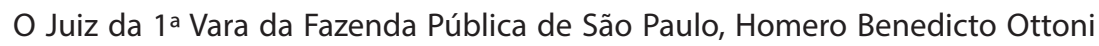
Netto, com base em uma leitura correta da Constituição, determinou a realização de

85 Cf. FERRAZ JR., Tercio Sampaio. Teoria da norma jurídica. 4. ed. Rio de Janeiro: Forense, 2002, p. 39 et seq.; WATZLAWICK, Paul; BEAVIN, Janet Helmick; JACKSON, Don D. Pragmática da comunicação humana. Tradução: Álvaro Cabral. 21. ed. São Paulo: Cultrix, 2010, p. 77-81.

86 Cf. MARTINS, Ricardo Marcondes. Justiça deôntica. In: PIRES, Luis Manuel Fonseca; MARTINS, Ricardo Marcondes. Um diálogo sobre a justiça. Belo Horizonte: Fórum, 2012, p. 172-179. Para um aprofundamento: DIÁLOGOS sobre desobediência civil e Direito. Direção, produção e roteiro: André Ricardo dos Santos Lopes. São Paulo: produção independente. Disponível em: https://www.youtube.com/watch?v=ruhOftrztHM. Acesso em: 15 mar. 19.

87 Cf. MARTINS, Ricardo Marcondes. Estudos de direito administrativo neoconstitucional. São Paulo: MaIheiros, 2015, p. 506 et seq. 
perícia prévia, feita às pressas, quando do pedido de imissão na posse, e condicionou o deferimento da imissão ao depósito integral do valor definido na perícia ${ }^{88}$. A partir de então, consagrou-se esse entendimento na primeira e na segunda instância do Poder Judiciário: os magistrados em geral vêm desprezando a orientação do STF e exigindo, para o deferimento da imissão na posse, o depósito integral do valor fixado na perícia prévia. Devem ser sancionados? A atitude é perfeitamente legítima, sendo descabida qualquer sanção. Suponha-se que, numa falência institucional generalizada, os magistrados passem a adotar a posição do STF. Nesse caso, o Poder Executivo deveria acatá-la? É, da mesma forma, legítimo o descumprimento, sendo despropositado sancionar o agente administrativo. O próprio advogado público deverá requerer a realização da perícia prévia e exigir da Administração que deposite, antes da imissão na posse, o valor integral que nela for fixado. Quando a decisão do Poder Judiciário configurar uma solução drasticamente imoral e gravemente injusta, impõe-se, juridicamente, seu descumprimento. Nesse caso, o descumprimento de ordem judicial dá-se dentro do Estado de Direito, pois consiste no correto cumprimento da Constituição vigente. Se isso vale para casos pontuais de descumprimento do Direito, vale, com mais razões, para situações de generalizado descumprimento. Por isso, mesmo dogmaticamente, tendo em vista uma compreensão correta do Direito vigente, no estado de exceção ilícito devem os juristas descumprir a deliberação do Poder Judiciário ${ }^{89}$.

\section{CONCLUSÃO}

1. Do ponto de vista sociológico é indiscutível que o Poder Judiciário brasileiro é fonte de um permanente estado de exceção para os miseráveis. O que se pretendeu neste estudo foi examinar sob uma perspectiva jurídico-dogmática a relação entre o Poder Judiciário e o estado de exceção tendo em vista uma compreensão normativista do Direito.

2. Diferenciou-se o estado de exceção lícito do estado de exceção ilícito. O primeiro decorre das situações disciplinadas nos arts. 136 a 141 da CF/88, que tratam do estado de defesa e do estado de sítio. Ambos são situações próprias do Estado de direito em que se admitem restrições a certos direitos fundamentais não admitidas fora delas. Por isso, considerou-se inapropriado afirmar que nessas situações vigora uma "legalidade extraordinária"; vigora, sim, a "legalidade normal", pois as "medidas extraordinárias"

88 MARTINS, Ricardo Marcondes. Estudos de direito administrativo neoconstitucional. São Paulo: Malheiros, 2015, p. 508-509. Kiyoshi Harada relata o caso e apresenta, na íntegra, a decisão, mas a considera exemplo de ativismo judicial (HARADA, Kiyoshi. Desapropriação. 7. ed. São Paulo: Atlas, 2007, p. 104 et seq.). Nos termos aqui expostos, o que para uns é ativismo para outros é o correto cumprimento do Direito.

89 A conclusão evidencia o dilema de todo jurista. Sobre o tema: MARTINS, Ricardo Marcondes. Jurista, de que lado você está? Revista Colunistas de Direito do Estado, n. 193, 17 jun. 2016. Disponível em: http://goo.gl/ BcNY9v. Acesso em: 15 mar. 19. 
nelas admitidas são disciplinadas na Constituição e nas leis. De modo a confirmar essa conclusão, a Constituição estabelece expressamente um denso controle político e jurisdicional desses estados de exceção.

3. O estado de exceção ilícito, ao contrário do lícito, é atentatório ao Estado de Direito; decorre da falência das instituições estatais na realização de sua missão constitucional.

4. A função jurisdicional destina-se a dar a última palavra sobre a interpretação jurídica. A decisão jurisdicional é um ato cognitivo, e não volitivo, fruto de competência vinculada, e não discricionária. O juiz, oráculo do Direito, deve buscar a decisão justa. Para tanto, deve ser imparcial, mais do que impessoal.

5. Repudiou-se a concepção realista do Direito: este não é o que magistrado diz, mas a interpretação correta dos textos normativos vigentes. Sendo humano e, pois, falível, o magistrado pode errar na interpretação. Há, contudo, uma regra de calibração: com o trânsito em julgado o erro do magistrado é assimilado como acerto. Fixaram-se três conclusões. Primeira: essa regra não atua da mesma forma no controle concentrado; a decisão da Corte Constitucional não impede, no Direito, a rediscussão futura. Segunda: essa regra não é absoluta, daí a teoria da coisa julgada inconstitucional. Terceira: quanto mais erra, mais o magistrado perde prestígio.

6. Por força da referida regra de calibração, erros do Judiciário não são suficientes para caracterizar um estado de exceção. Contudo, a calibração não funciona quando os equívocos do Poder Judiciário não decorrem apenas de um equívoco de interpretação, mas de um problema institucional. Considerou-se a atuação do STF durante a Ditadura militar um exemplo de estado de exceção ilícito. Os Ministros não atuaram em um cenário de isenção que lhes possibilitasse buscar, com base em suas convicções exegéticas, a interpretação correta do ordenamento vigente. A regra de calibração só atua quando as condições institucionais necessárias para o exercício da jurisdição estão presentes.

7. Costuma-se utilizar a expressão "ativismo judicial" para criticar a correta interpretação jurisdicional que se afasta da literalidade dos textos normativos. No Estado Legalista, considerava-se que o Judiciário violava a separação dos Poderes quando se afastava da literalidade. No Estado neoconstitucionalista, em que a Constituição é considerada uma ordem objetiva de valores, a correta compreensão do Direito pressupõe a percepção de muitas normas implícitas. Atualmente, toda política juridiciza-se, configurando exercício de competência discricionário, sujeito a controle jurisdicional. $\mathrm{O}$ verdadeiro ativismo judicial não se dá quando o magistrado desvenda corretamente normas implícitas ou quando constata a invalidade do exercício da discricionaridade, mas quando desrespeita o exercício válido de competência discricionária. 
8. Diferenciou-se a resistência ativa, que se apresenta em face da execução de atos administrativos inexistentes, da resistência passiva, que se apresenta em face de certos atos administrativos inválidos. Se o Judiciário errar na compreensão da inexistência ou da invalidade jurídica, regra geral, não há, respectivamente, direito de resistência ativa e passiva. A resistência política contra o erro do Judiciário é considerada violação do Direito: só se legitima fora do Estado de Direito, mediante a substituição da ordem vigente.

9. Concluiu-se, contudo, que em certas hipóteses excepcionais, de erros judiciais manifestos, é legítimo, sem rompimento do Estado de Direito e, pois, do direito vigente, o descumprimento do ato jurisdicional. Quando a decisão do Poder Judiciário configurar uma solução drasticamente imoral e gravemente injusta, impõe-se, juridicamente, seu descumprimento.

\section{REFERÊNCIAS}

ALEXY, Robert. Teoria dos direitos fundamentais. Tradução: Virgílio Afonso da Silva. São Paulo: Malheiros, 2008.

ALEXY, Robert. Constitucionalismo discursivo. Tradução: Luís Afonso Heck. Porto Alegre: Livraria do Advogado, 2007.

ARAÚJO, Luiz Fernando Diniz. O ativismo judicial e constrangimentos a posteriori. Revista de Investigações Constitucionais, Curitiba, vol. 5, n. 1, p. 129-150, jan./abr. 2018.

ARENDT, Hannah. Eichmann em Jerusalém. Tradução: José Rubens Siqueira. 12. reimpr. São Paulo: Companhia das Letras, 1999.

ÁVILA, Ana Paula Oliveira. O princípio da impessoalidade da Administração Pública: para uma administração imparcial. Rio de Janeiro: Renovar, 2004.

BANDEIRA DE MELLO, Celso Antônio. Serviço público e concessão de serviço público. São Paulo: Malheiros, 2017.

BANDEIRA DE MELLO, Celso Antônio. Juízo liminar: poder-dever de exercício do poder cautelar nessa matéria. Revista trimestral de direito público, São Paulo, n. 3, p. 106-116, 1993.

BANDEIRA DE MELLO, Celso Antônio. Mandado de segurança contra denegação ou concessão de liminar. Revista de direito administrativo e infraestrutura - RDAI, São Paulo, n. 11, ano 3, p. 441-449, out./dez. 2019.

BANDEIRA DE MELLO, Celso Antônio. A democracia e suas dificuldades contemporâneas. Revista Trimestral de Direito Público, São Paulo, n. 15, p. 100-111, 1996.

BANDEIRA DE MELLO, Celso Antônio. Curso de direito administrativo. 33. ed. São Paulo: Malheiros, 2016. 
BANDEIRA DE MELLO, Oswaldo Aranha. A teoria das constituições rígidas. 2. ed. São Paulo: José Bushatsky, 1980.

BARROSO, Luís Roberto. $\mathbf{O}$ controle de constitucionalidade no direito brasileiro. São Paulo: Saraiva, 2004.

BOBBIO, Norberto. $O$ positivismo jurídico: lições de filosofia do Direito. Tradução e notas: Márcio Pugliesi et al. São Paulo: Ícone, 1995.

BRITTO, Carlos Ayres. O humanismo como categoria constitucional. Belo Horizonte: Fórum, 2007.

CAMPOS, Carlos Alexandre de Azevedo. Estado de coisas inconstitucional. Salvador: Juspoivm, 2016.

CINTRA, Antonio Carlos de Araújo; GRINOVER, Ada Pellegrini; DINAMARCO, Cândido Rangel. Teoria geral do processo. 11 ed. São Paulo: Malheiros, 1995.

DAVID, René. Os grandes sistemas do direito contemporâneo. Tradução: Hermínio A. Carvalho. São Paulo: Martins Fontes, 2002.

DIÁLOGOS sobre desobediência civil e Direito. Direção, produção e roteiro: André Ricardo dos Santos Lopes. São Paulo: produção independente. Disponível em: https://www.youtube.com/ watch?v=ruhOftrztHM. Acesso em: 15 mar. 19.

DINAMARCO, Cândido Rangel. Instituições de direito processual civil - v. I. São Paulo: Malheiros, 2001.

DINAMARCO, Cândido Rangel. Relativizar a coisa julgada material. In: NASCIMENTO, Carlos Valder do. (coord.). Coisa julgada inconstitucional. 2. ed. Rio de Janeiro: América Jurídica, 2002. p. 33-76.

DWORKIN, Ronald. $O$ império do direito. Tradução: Jefferson Luiz Camargo. 1. ed. 2. tir. São Paulo: Martins Fontes, 2003.

DWORKIN, Ronald. Levando os direitos a sério. Tradução: Nelson Boeira. São Paulo: Martins Fontes, 2002.

FAUSTO, Boris. História do Brasil. 5. ed. São Paulo: Editora da Universidade de São Paulo, 1997.

FERRAZ JR., Tercio Sampaio. Introdução ao estudo do direito. 5. ed. São Paulo: Atlas, 2007.

FERRAZ JR., Tercio Sampaio. Teoria da norma jurídica. 4. ed. Rio de Janeiro: Forense, 2002.

FERRAZ JR., Tercio Sampaio. Argumentação jurídica. Barueri: Manole, 2014.

FIGUEIREDO, Marcelo. O ativismo do Supremo Tribunal Federal e a ausência de critérios claros em matéria de direitos fundamentais. A\&C - Revista de Direito Administrativo \& Constitucional, Belo Horizonte, ano 18, n. 74, p. 97-123, out./dez. 2018. 
FONSECA, João Francisco. O processo do mandado de injunção. São Paulo: Saraiva, 2016.

GUASTINI, Riccardo. Las fuentes del derecho: fundamentos teóricos. Tradução: César E. Moreno More e Luis Cárdenas Rodríguez. Lima: Raguel, 2016.

GUIMARÃES, Hélio de Seixas; LESSA, Ana Cecília. Figuras de linguagem: teoria e prática. 14. ed. São Paulo: Atual, 2003.

HARADA, Kiyoshi. Desapropriação. 7. ed. São Paulo: Atlas, 2007.

HART, Herbert Lionel Adolphus. O conceito de direito. Tradução: A. Ribeiro Mendes. 3. ed. Lisboa: Calouste Gulbenkian, 2001.

HESSE, Konrad. A interpretação constitucional. Tradução: Inocêncio Mártires Coelho. In: HESSE, Konrad. Temas fundamentais do direito constitucional. São Paulo: Saraiva, 2009. p. 101 a 122.

KELSEN, Hans. Teoria pura do Direito. Tradução: João Baptista Machado. 6. ed. Coimbra: Armênio Amado Editora, 1984.

LEAL, Rogério Gesta. Riscos e possibilidades do ativismo judicial na democracia. A\&C - Revista de Direito Administrativo \& Constitucional, Belo Horizonte, ano 21, n. 83, p. 119-135, jan./mar. 2021.

LEAL, Rogério Gesta. Sociedade de riscos e estado de exceção: encruzilhadas em labirintos. A\&C - Revista de Direito Administrativo \& Constitucional, Belo Horizonte, ano 19, n. 75, p. 179-193, jan./mar. 2019.

LIMA, Gabriela Eulalio de; ANDRADE, Sinara Lacerda. O estado de coisas inconstitucional e a crise financeira à luz da economia compartilhada. Revista de Direito Econômico e Socioambiental, Curitiba v. 11, n. 3, p. 193-212, set./dez. 2020.

MACHADO, Maira Rocha. Quando o estado de coisas é inconstitucional: sobre o lugar do Poder Judiciário no problema carcerário. Revista de Investigações Constitucionais, Curitiba, vol. 7, n. 2, p. 631-664, maio/ago. 2020.

MARTINS, Ricardo Marcondes. Teoria jurídica da liberdade. São Paulo: Contracorrente, 2015.

MARTINS, Ricardo Marcondes. Direito fundamental de acesso à informação. A\&C - Revista de Direito Administrativo \& Constitucional, Belo Horizonte, ano 14, n. 56, p. 127-146, abr./jun. 2014. MARTINS, Ricardo Marcondes. Paradoxo da interpretação literal. Revista Colunistas de Direito do Estado, n. 102, 07 mar. 2016. Disponível em: http://goo.gl/bneUDH. Acesso em: 06 mar. 19. MARTINS, Ricardo Marcondes. Efeitos dos vícios do ato administrativo. São Paulo: Malheiros, 2008.

MARTINS, Ricardo Marcondes. Teoria geral da interpretação jurídica: considerações críticas à obra de Black. Revista de Direito Administrativo e Infraestrutura (RDAI), São Paulo, ano 1, v. 3, p. 299-331, out./dez. 2017. 
MARTINS, Ricardo Marcondes. Direito e justiça. In: PIRES, Luis Manuel Fonseca; MARTINS, Ricardo Marcondes. Um diálogo sobre a justiça. Belo Horizonte: Fórum, 2012, p. 43-91.

MARTINS, Ricardo Marcondes. Produção científica do direito administrativo. Revista Colunistas de Direito do Estado, n. 393, 22 abr. 2018. Disponível em: https://goo.gl/f2U4oC. Acesso em: 07 mar. 19.

MARTINS, Ricardo Marcondes. Abuso de direito e a constitucionalização do direito privado. São Paulo: Malheiros, 2010.

MARTINS, Ricardo Marcondes. Neoconstitucionalismo: perscrutação sobre a pertinência do prefixo. Revista Internacional de Direito Público (RIDP), Belo Horizonte, ano 2, n. 3, p. 9-37, jul./ dez. 2017.

MARTINS, Ricardo Marcondes. Três planos da norma jurídica. Revista Colunistas de Direito do Estado, n. 238, 19 ago. 2016. Disponível em: http://goo.gl/HuK5bc. Acesso em: 15 mar. 19.

MARTINS, Ricardo Marcondes. Justiça deôntica. In: PIRES, Luis Manuel Fonseca; MARTINS, Ricardo Marcondes. Um diálogo sobre a justiça. Belo Horizonte: Fórum, 2012. p. 149-244.

MARTINS, Ricardo Marcondes. Estudos de direito administrativo neoconstitucional. São Paulo: Malheiros, 2015.

MARTINS, Ricardo Marcondes. Jurista, de que lado você está? Revista Colunistas de Direito do Estado, n. 193, 17 jun. 2016. Disponível em: http://goo.gl/BcNY9v. Acesso em: 15 mar. 19.

MAZZUOLI, Valerio de Oliveira. Direitos humanos na jurisprudência internacional: sentenças, opiniões consultivas, decisões e relatórios internacionais. Rio de Janeiro: Forense, 2019.

MAZZUOLI, Valerio de Oliveira; GOMES, Luiz Flavio. Crimes da ditadura militar e o “Caso Araguaia": aplicação do direito internacional dos direitos humanos pelos juízes e tribunais brasileiros. São Paulo: Revista dos Tribunais, 2011.

MELO NETO, João Cabral de. Morte e vida severina. In: MELO NETO, João Cabral de. Serial e antes. Rio de Janeiro: Nova Fronteira, 1997. p. 143-180.

MONTESQUIEU. Do espírito das leis. Tradução: Fernando Henrique Cardoso e Leôncio Martins Rodrigues. 2. ed. São Paulo: Abril Cultural, 1979.

MOTA, Carlos Guilherme. A revolução francesa. 2. ed. São Paulo: Perspectiva, 2013.

MÜLLER, Friedrich. Métodos de trabalho do direito constitucional. 2. ed. Tradução: Peter Naumann. São Paulo: Max Limonad, 2000.

OLIVECRONA, Karl. Linguagem jurídica e realidade. Tradução: Edson L. M. Bini. São Paulo: Quartier Latin, 2005. 
OS ADVOGADOS contra a ditadura. Direção, roteiro e texto: Silvio Tendler. Produção: Maycon Almeida, 2014. Disponível em: http://caliban.com.br/filmografia_/os-advogados-contra-a-ditadura/. Acesso em: 13 mar. 19.

PONTES DE MIRANDA, Francisco Cavalcanti. Tratado da ação rescisória. Campinas: Bookseller, 1998.

PONTES DE MIRANDA, Francisco Cavalcanti. Tratado das ações - v. l. Campinas: Bookseller, 1998. RECONDO, Felipe. Tanques e togas: o STF e a ditadura militar. São Paulo: Companhia das Letras, 2018.

RELATÓRIO da Comissão Nacional da Verdade. 10 dez. 2014. Disponível em: http://cnv.memoriasreveladas.gov.br. Acesso em: 13 mar. 19.

RELATÓRIO da Comissão da Verdade da Prefeitura de São Paulo. 14 dez. 2016. Disponível em: https://www.prefeitura.sp.gov.br/cidade/secretarias/direitos_humanos/comissao_da_memoria_e_ verdade/noticias/?p=227198. Acesso em: 13 mar. 19.

RIGAUX, François. A lei dos juízes. Tradução: Edmir Missio. 1. ed. 2. tir. São Paulo: Martins Fontes, 2000.

ROUSSEAU, Jean-Jacques. O contrato social. Tradução: Antônio de P. Machado. Rio de Janeiro: Ediouro, [19-].

ROXIN, Claus. A proteção de bens jurídicos como função do Direito Penal. Tradução: André Luís Callegari e Nereu José Giacomolli. Porto Alegre: Livraria do Advogado, 2006.

SANTIAGO NINO, Carlos. Introdução à análise do direito. Tradução: Elza Maria Gasparotto. São Paulo: WMF Martins Fontes, 2015.

SCHWABE, Jürgen. Cinquenta anos de jurisprudência do tribunal constitucional federal alemão. Tradução Beatriz Hennig et al. Montevideo: Konrad-Adenauer-Stiftung, 2005.

SERRANO, Pedro Estevam Alves Pinto. Autoritarismo e golpes na América Latina. São Paulo: Alameda, 2016.

SERRANO, Pedro Estevam Alves; MAGANE, Renata Possi. A governabilidade de exceção permanente e a política neoliberal de gestão dos indesejáveis no Brasil. Revista de Investigações Constitucionais, Curitiba, vol. 7, n. 2, p. 517-547, maio/ago. 2020.

SICHES, Luis Recasens. Introducción al estudio del derecho. 15. ed. México: Porrúa, 2006.

SILVA, José Afonso. Curso de direito constitucional positivo. 11. ed. São Paulo: Malheiros, 1996. SILVA, José Afonso. Aplicabilidade das normas constitucionais. 4. ed. São Paulo: Malheiros, 2000.

SILVA, José Afonso. Teoria do conhecimento constitucional. São Paulo: Malheiros, 2014. 
SILVA, Virgílio Afonso da. Direitos fundamentais. São Paulo: Malheiros, 2009.

SOUZA, Artur César de. A parcialidade positiva do juiz. São Paulo: Revista dos Tribunais, 2008.

TÁCITO, Caio. O abuso de poder administrativo no Brasil. In:TÁCITO, Caio. Temas de direito público: estudos e pareceres - v. 1. Rio de Janeiro: Renovar, 1997. p. 39-70.

WATZLAWICK, Paul; BEAVIN, Janet Helmick; JACKSON, Don D. Pragmática da comunicação humana. Tradução: Álvaro Cabral. 21. ed. São Paulo: Cultrix, 2010.

ZAGREBELSKY, Gustavo. El derecho dúctil: ley, derecho, justicia. Tradução: Marina Gascón. Madri: Trotta, 2005. 